\title{
The same, only different - DNA damage checkpoints and their reversal throughout the cell cycle
}

\author{
Indra A. Shaltiel ${ }^{\ddagger}$, Lenno Krenning ${ }^{\ddagger}$, Wytse Bruinsma* and René H. Medema ${ }^{\S}$
}

\begin{abstract}
Cell cycle checkpoints activated by DNA double-strand breaks (DSBs) are essential for the maintenance of the genomic integrity of proliferating cells. Following DNA damage, cells must detect the break and either transiently block cell cycle progression, to allow time for repair, or exit the cell cycle. Reversal of a DNA-damageinduced checkpoint not only requires the repair of these lesions, but a cell must also prevent permanent exit from the cell cycle and actively terminate checkpoint signalling to allow cell cycle progression to resume. It is becoming increasingly clear that despite the shared mechanisms of DNA damage detection throughout the cell cycle, the checkpoint and its reversal are precisely tuned to each cell cycle phase. Furthermore, recent findings challenge the dogmatic view that complete repair is a precondition for cell cycle resumption. In this Commentary, we highlight cell-cycle-dependent differences in checkpoint signalling and recovery after a DNA DSB, and summarise the molecular mechanisms that underlie the reversal of DNA damage checkpoints, before discussing when and how cell fate decisions after a DSB are made.
\end{abstract}

KEY WORDS: DNA damage checkpoints, Recovery, Competence, Adaptation, Wip1, Plk1

\section{Introduction}

The current dogma is that the DNA damage response (DDR) affects proliferation such that the DDR can reversibly arrest cell cycle progression to allow time for DNA repair, and, upon completion of DNA repair, the DDR is turned off to allow cell cycle resumption (Box 1). It is becoming increasingly clear that the DDR not only communicates to the cell cycle machinery, but that the cell cycle machinery is also involved in regulating the DDR, such that a similar DNA break activates different arms of the DDR depending on the cell cycle phase in which the damage occurs. In turn, silencing of the DDR is different in each cell cycle phase. These cell-cycle-dependent changes are intimately intertwined with double-strand break (DSB) end-processing and the usage of non-homologous end-joining (NHEJ) and homologous recombination (HR) repair pathways. In this Commentary, we address differences in the response to DSBs throughout the cell cycle in metazoan cells, highlighting which arms of the DDR function in the different phases. We also discuss how DNA-damage-induced checkpoints

\footnotetext{
The Netherlands Cancer Institute, Division of Cell Biology, Plesmanlaan 121, 1066 CX Amsterdam, The Netherlands.

*Present address: Molecular Biology Program, Memorial Sloan-Kettering Cancer Center, New York, NY 10065, USA.

†These authors contributed equally to this work

§Author for correspondence (r.medema@nki.nl)
}

are silenced in the different cell cycle phases, how cells undergo checkpoint recovery after checkpoint silencing and how cells, when arrested, maintain reversibility of the arrest.

\section{DNA damage checkpoints after DSBs throughout the cell cycle}

Central to the response to a DSB is its recognition by the MRN (Mre11, Rad50 and Nbs1) complex and the subsequent recruitment and activation of the ataxia telangiectasia mutated (ATM) kinase, which is conserved throughout the cell cycle (Giunta et al., 2010; Lee and Paull, 2005). Subsequent activation of various arms of the DDR is precisely tuned to each cell cycle phase as discussed below (Fig. 1).

\section{G1}

ATM phosphorylates S139 on histone variant H2AX (yielding $\gamma \mathrm{H} 2 \mathrm{AX})$ on the DNA adjacent to a DSB, which is recognised by mediator proteins that amplify local ATM activity and recruit repair factors (Burma et al., 2001; Lou et al., 2006; Stucki and Jackson, 2006). In addition, ATM activates the Chk2 kinase that disseminates from the site of damage and contributes to the DDR (Matsuoka et al., 1998). In response to a DSB in G1, ATM and Chk2 are required for the stabilisation of $\mathrm{p} 53$, which in turn results in the induction of a large variety of transcriptional targets, among which the cyclindependent kinase (Cdk) inhibitor protein p21 (also known as CDKN1A) (Harper et al., 1993; Harper et al., 1995). Accumulated p21 binds to and inhibits cyclin-Cdk complexes to block cell cycle progression, and loss of p53 or p21 results in complete loss of the G1 checkpoint (Deng et al., 1995; Hirao et al., 2002; Kastan et al., 1991). ATM also activates the p38 MAPK family, which contributes to the G1 checkpoint through stabilisation of p21-encoding mRNA (Lafarga et al., 2009; Reinhardt et al., 2007). This relatively slow transcriptional response is complemented by ATM-, Chk2- and p38dependent pathways that rapidly, but transiently, prevent S-phase entry by promoting the degradation of cyclin D and the Cdc25A phosphatase that reverses inhibitory phosphorylation of Cdk2 (at T14 and Y15) (Agami and Bernards, 2000; Deckbar et al., 2010; Mailand et al., 2000; Reinhardt et al., 2007; Santra et al., 2009).

\section{S-phase}

Once Cdk2 activity initiates DNA replication, DSBs can trigger entirely different signalling responses as some broken ends are not 'simply' religated by NHEJ (for a review, see Ochi et al., 2014; Deriano and Roth, 2013) but instead are repaired by HR, which involves the extensive $5^{\prime}-3^{\prime}$ resection of the broken ends to produce a $3^{\prime}$ overhang. The process of DNA end-resection commits repair to HR and is tightly controlled such that HR only takes place when a sister template is available in S- or G2-phase (Ira et al., 2004). The single-stranded DNA (ssDNA) generated by resection activates the ataxia telangiectasia and Rad3-related 


\section{Box 1. DNA damage response and the cell cycle}

DNA damage poses a constant threat to genomic integrity owing to its mutagenic potential. Under normal physiological conditions cells undergo many DNA lesions every day. The vast majority of these lesions are repaired without further consequences, but mutations resulting from incorrect repair can contribute to cellular dysfunction and tumorigenesis. Extensive or prolonged exposure to DNAdamaging agents can cause cell death or cellular senescence. DSBs are a particularly deleterious type of lesion that can cause structural chromosomal rearrangements and chromosome segregation errors when incorrectly repaired (Hoeijmakers, 2009). In order to cope with DNA damage, cells have evolved elaborate signalling cascades, collectively known as the DDR, that detect DNA damage, coordinate DNA repair and, in proliferating cells, halt cell cycle progression (Ciccia and Elledge, 2010). Cell cycle transitions are driven by Cdks that require cyclin binding for their activity and substrate selectivity. Cyclins are subject to strict transcriptional and post-transcriptional regulation to ensure cell cycle-specific expression, and Cdks themselves are regulated by activating and inhibitory phosphorylation (Pines, 1995). The DDR curbs the activity of cyclin-Cdk complexes to elicit a cell cycle arrest in G1- or G2-phase, or to slow down replication in S-phase, but the DDR does not directly impede the completion of mitosis (Mikhailov et al., 2002). Following DNA damage checkpoint silencing, cells can resume the cell cycle, a process known as checkpoint recovery.

(ATR) kinase (Zou and Elledge, 2003), thus promoting a switch from DNA damage signalling exclusively by ATM and Chk2 kinases in G1 to additional contributions of ATR and its effector Chk1 kinase in S-phase and G2. This activation of ATR and Chk1 kinases also occurs as a consequence of replication, when the replication fork generates single-strand DNA (ssDNA) (Paulsen and Cimprich, 2007). Cdk2 phosphorylates the key exonucleases CtIP (also known as RBBP8) and Exo1 to enable DNA endresection and ensure that end-resection occurs only after S-phase entry (Buis et al., 2012; Tomimatsu et al., 2014; Wang et al., 2013). In addition, Cdk2-dependent, activating phosphorylations of the ATR-interacting protein ATRIP (at S224) and Chk1 itself (at S286 and S301) further restrict full activation of ATR and Chk1 to S- and G2-phase (Myers et al., 2007; Xu et al., 2012). Entry into S-phase thus drastically changes the signalling cascades that are elicited by a DSB.

Even though ATM, ATR, Chk2 and Chk1 all contribute to the stabilisation of p53 (Meek and Anderson, 2009), downstream p21 accumulation is prevented during DNA replication by the PCNAassociated CRL4 ${ }^{\text {Cdt2 }}$ ubiquitin ligase (a cullin4A RING E3 ubiquitin ligase complex containing $\mathrm{Cdt} 2$ ), which is present on the replication fork (Abbas et al., 2008; Havens and Walter, 2011; You et al., 2002). Interfering with p21 degradation in S-phase compromises the control over origin licensing and results in detrimental re-replication (Kim et al., 2008), underscoring the importance of this mode of checkpoint attenuation in S-phase. With the continuous degradation of $\mathrm{p} 21$, the intra-S checkpoint instead relies on Wee1 kinase, which becomes expressed in Sphase and phosphorylates Cdk2 to inhibit its activity (Chow et al., 2003; Watanabe et al., 1995). Chk1 and Chk2 deposit activating phosphates on Weel kinase and target the counteracting phosphatase Cdc25A for degradation to impose an immediate break on further Cdk activation (Beck et al., 2010; Hughes et al., 2013; O’Connell et al., 1997).

\section{G2}

Wee1-dependent phosphorylation of Cdks remains crucial for checkpoint control in G2. Wee1 inhibitors override the G2 checkpoint in p53 mutant cells (Hirai et al., 2009). In addition, the slower transcriptional induction of p21 that is reinstated in G2 is required for sustained inhibition of Cdk activity and cell cycle arrest (Bunz et al., 1998). In contrast to the checkpoint in response to DSBs in G1, a checkpoint arrest in G2 does not absolutely depend on ATM, p53 and p21. Although ATM and Chk 2 control the establishment of an arrest after damage (Painter and Young, 1980; Rainey et al., 2008), ATR- and Chk1dependent signals are essential for checkpoint maintenance in G2 (Brown and Baltimore, 2003; Liu et al., 2000; Shibata et al., 2010; Takai et al., 2000). Conversely, ATR and Chk1 are neither necessary nor sufficient for a G1 arrest in response to DSBs (Chen et al., 1999; Deckbar et al., 2010; Nghiem et al., 2001). This suggests that lesions engaged in HR are determinant for checkpoint maintenance in G2; this hypothesis is supported by a failure to maintain a G2 checkpoint arrest in the absence of PALB2 and BRCA2, which mediate strand invasion (Menzel et al., 2011). In addition, ATM- and ATR-dependent activation of p38 might contribute to the maintenance of a G2 checkpoint by inhibiting both Cdc25A and Cdc25B (Reinhardt et al., 2007).

\section{Mitosis}

The DDR is potently inhibited during mitosis, suggesting that at least some forms of mitotic DNA repair are undesirable. Even though a DSB sustained or generated in mitosis still activates ATM, downstream activation of Chk2 and recruitment of repair factors does not occur (Giunta et al., 2010; van Vugt et al., 2010). Mitotic attenuation of the DDR is enforced at various levels. The mitotic kinase Plk1 phosphorylates Chk2 on multiple sites to prevent its dimerization and recruitment to the DSB, both of which are required for its activation (van Vugt et al., 2010). Similarly, Plk1 abrogates Chk1 activation by inducing SCF ${ }^{\beta T R C P}$ (a SKP1-cullin-1-F-box complex that contains $\beta$ TRCP as the Fbox protein)-mediated degradation of the scaffold protein claspin that is required to bridge ATR and Chk1 (Mailand et al., 2006; Mamely et al., 2006; Peschiaroli et al., 2006). It is conceivable that checkpoint kinases that inhibit Cdks must be quelled to maintain the full Cdk activity that is necessary for the execution of mitosis. However, the mitotic inhibition of the DDR is not limited to the checkpoint. Cdk1 phosphorylates the ubiquitin ligase RNF8 (at S198) to prevent the formation of K63-linked polyubiquitin at damage sites (Orthwein et al., 2014). Additional phosphorylation of residues T1609 and S1618 of 53BP1 by Plk1 and an unidentified kinase interferes with its recruitment to damaged DNA (Lee et al., 2014; van Vugt et al., 2010). Phosphorylation of RNF8 and 53BP1 prevents DNA repair during mitosis (Orthwein et al., 2014). Additionally, Plk1 and Cdk1dependent phosphorylation of XRCC4 contributes to the suppression of NHEJ during mitosis (Terasawa et al., 2014). Collectively, these mechanisms eliminate most checkpoint signals and DNA repair in mitosis.

Although the picture is far from being complete, it has become clear that a myriad of mechanisms operate to fine-tune the DDR in each phase of the cell cycle. Attenuated checkpoint responses are necessary for the orderly completion of DNA replication in S-phase (Kim et al., 2008), to prevent deleterious fusions of telomeres in mitosis (Orthwein et al., 2014), and probably more. 
G1

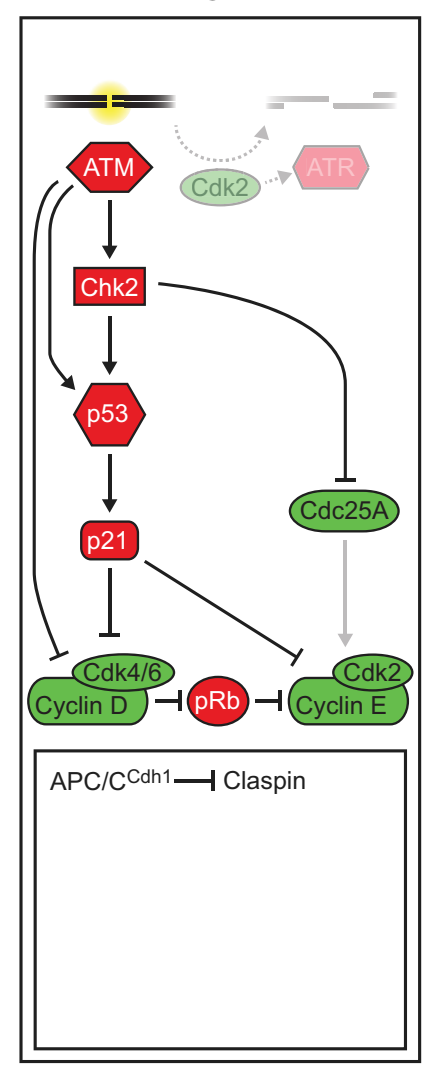

$\mathrm{S}$

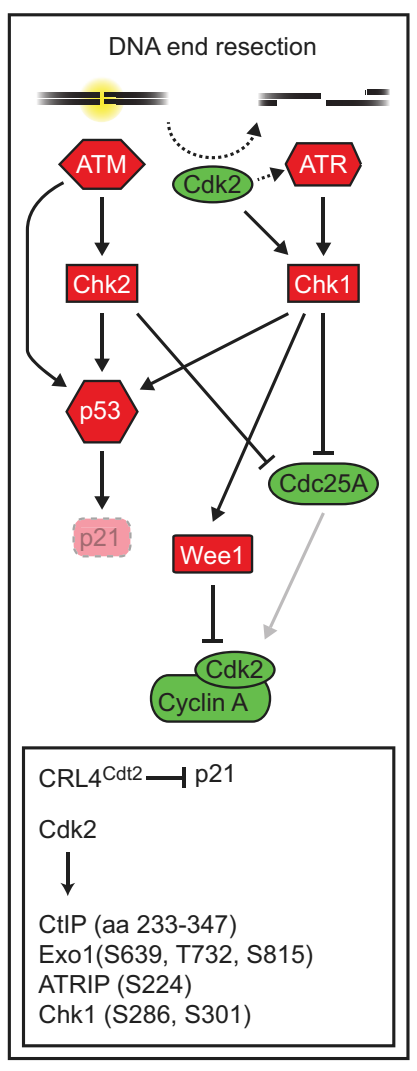

G2

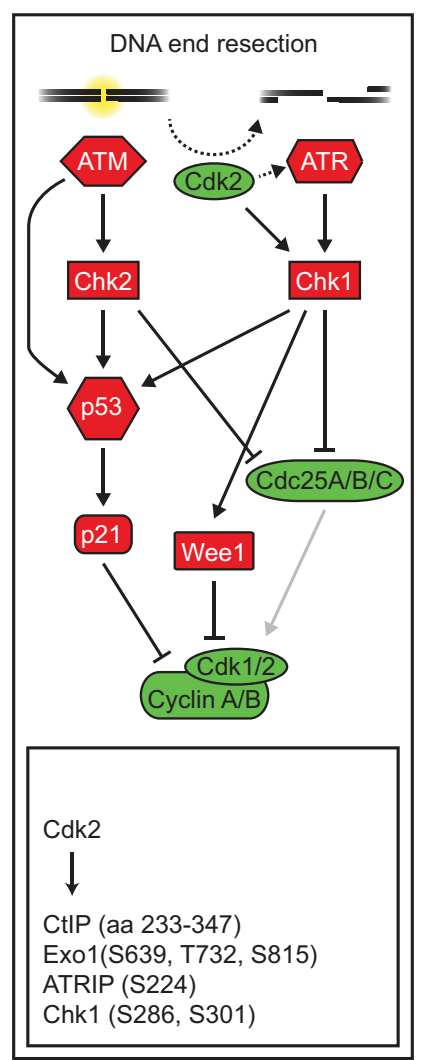

M

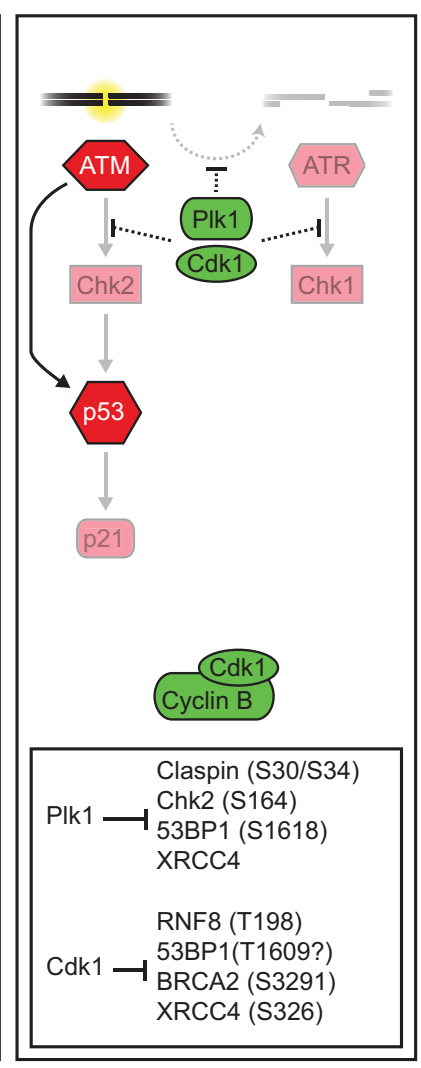

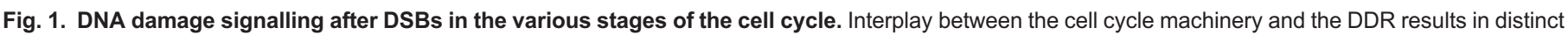
signalling in response to DSBs in different cell cycle phases. DSBs are recognised by the Mre11-Rad50-Nbs1 (MRN) complex, which subsequently

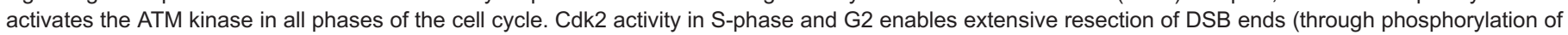
CtIP and Exo1) to promote HR, causing the additional activation of ATR kinase. Cdk2-dependent phosphorylation of ATRIP and Chk1 further restrict full

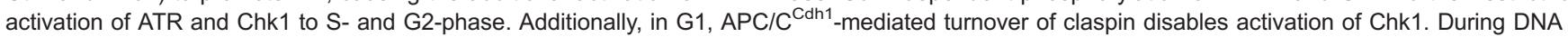

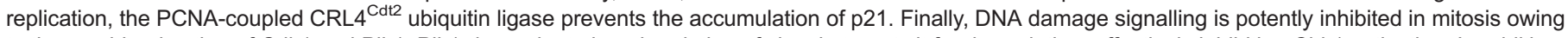

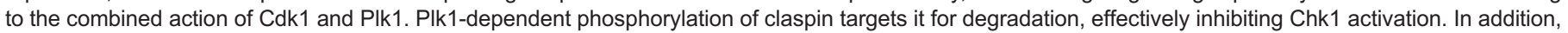
Plk1-dependent phosphorylation of Chk2 prevents Chk2 activation. Both Plk1 and Cdk1 phosphorylate and thereby inhibit the DNA repair proteins 53 BP1 and XRCC1, and Cdk1 additionally inhibits RNF8 and BRCA2, resulting in the inhibition of DNA repair during mitosis. The residue subjected to inhibiting or activating phosphorylation is shown in parentheses.

\section{Dismantling the DNA damage checkpoint}

Activation of the DDR leads to a highly complex series of events orchestrated by a plethora of posttranslational modifications (PTMs), such as phosphorylation, acetylation, methylation, poly(ADP-ribosyl)ation (PARylation), ubiquitylation and small ubiquitin-like modifier (SUMO)ylation. As these modifications trigger checkpoint activation, cell cycle arrest and DNA repair, removal of these modifications by dedicated enzymes or degradation of modified proteins is essential for checkpoint silencing and recovery. Thus far, this emerging field has identified redundancy and complex cross-talk between the modifications as a common theme, as discussed below.

\section{Direct reversal of PTMs}

Phosphorylation is the most widespread and best-studied PTM of the DDR. Many serine/threonine phosphatases are involved in dephosphorylation, and these proteins act in a largely redundant manner (Fig. 2) (Lee and Chowdhury, 2011; Shimada and Nakanishi, 2013). For instance, PP2A (in complex with the B55 $\alpha$ and B56e subunits), PP4, PP6 and Wip1 all dephosphorylate $\gamma \mathrm{H} 2 \mathrm{AX}$ in vitro and control $\gamma \mathrm{H} 2 \mathrm{AX}$ levels in vivo (Chen et al., 2014; Chowdhury et al., 2005; Chowdhury et al., 2008; Douglas et al., 2010; Macůrek et al., 2010). This redundancy is most likely a reflection of different spatiotemporal regulation of these phosphatases during the DDR. Indeed, PP2A phosphatase activity towards $\gamma \mathrm{H} 2 \mathrm{AX}$-containing nucleosomes is repressed in the first hour, but increases by twofold 5 hours after DSB induction by camptothecin (Chen et al., 2014). PP1, PP2A, Wip1 and PP6 are regulated through distinct mechanisms by DNA damage, and both PP2A and Wip1 have been shown to accumulate at DSBs (Chen et al., 2014; Chowdhury et al., 2005; Dozier et al., 2004; Guo et al., 2002; Macůrek et al., 2010; Naito et al., 2012; Shouse et al., 2011), whereas PP4 appears to be selective for chromatin-dissociated $\gamma \mathrm{H} 2 \mathrm{AX}$ in yeast (Keogh et al., 2006), revealing that these phosphatases modulate specific pools of $\gamma \mathrm{H} 2 \mathrm{AX}$ at different times. Although less thoroughly assessed for other checkpoint phosphorylation events, redundancy and spatiotemporal regulation are a recurrent theme. For example, phosphorylated ATM (S1981) and Chk2 (T68) are both dephosphorylated by PP1, PP2A and Wip1 (Carlessi et al., 2010; Dozier et al., 2004; Fujimoto et al., 2006; Goodarzi et al., 2004; Liang et al., 2006; Peng et al., 2010; Shreeram et al., 2006). Recognition of T68-phosphorylated Chk2 by the B56 $\alpha$ subunit of PP2A can be prevented by additional ATM-dependent 


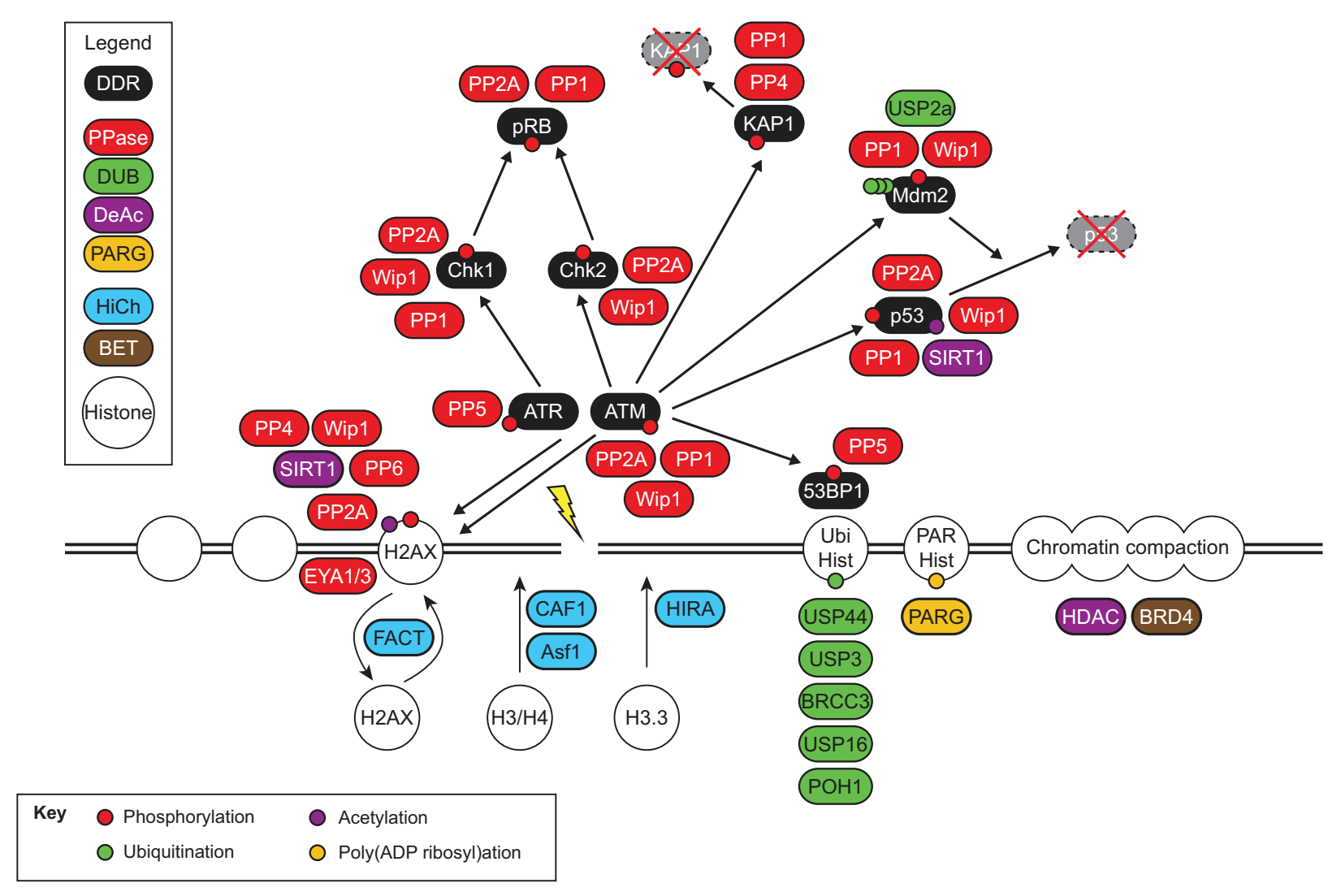

Fig. 2. Dismantling the DNA damage checkpoint. The DDR results in the generation of many PTMs in order to execute a cell cycle arrest. Thus, recovering from the DNA damage checkpoint requires reversal of phosphorylation by phosphatases (PPase; red), ubiquitylation by deubiquitinases (DUB; green), acetylation by deacetylases (DeAc; purple), poly(ADP-ribosyl) (PAR) modification by PAR glycohydrolase (PARG; yellow), as well as the structural rearrangement of the chromatin by histone chaperones (HiCh; blue) and the bromodomain and extra-terminal family of proteins (BET; brown). The presently identified enzymes that act on central components of the DDR are displayed. Aside from PTM reversal, activated checkpoint components can also be removed either by proteasomal degradation, as is the case for p53 and phosphorylated KAP1 (Kuo et al., 2014) (indicated by the red cross), or by exchange, as occurs with $\gamma \mathrm{H} 2 \mathrm{AX}$ in a process mediated by the histone chaperone FACT. Chromatin compaction is another important impediment of the DDR. Histone deacetylases (Murga et al., 2007) and the condensin II chromatin remodelling complex recruiter BRD4 (Floyd et al., 2013) promotes chromatin compaction and restrict spreading of DDR signalling on chromatin. Finally, after repair has taken place the histone chaperones Asf1, Caf1 and HIRA are required for restoring nucleosomes at the site of damage. For further details see: USP2a-dependent deubiquitination of Mdm2 (Stevenson et al., 2007); dephosphorylation of ATR (Zhang et al., 2005), Chk1 (den Elzen and O'Connell, 2004; Leung-Pineda et al., 2006; Lu et al., 2005), 53BP1 (Kang et al., 2009) and pRB (Alberts et al., 1993; Cicchillitti et al., 2003; Ludlow et al., 1993); deacetylation of p53 (Luo et al., 2001; Vaziri et al., 2001) and $\gamma \mathrm{H} 2 \mathrm{AX}$ (Yamagata and Kitabayashi, 2009); and the removal of (PAR)-groups by PARG (Illuzzi et al., 2014).

phosphorylation of Chk2 at S33 and/or S35, suggesting that T68 dephosphorylation is facilitated by prior loss of ATM activity and dephosphorylation of S33 and/or S35 by an additional phosphatase (Freeman et al., 2010). Formation of a Chk2-Wip1 complex, by contrast, requires Chk2 kinase activity (Yoda et al., 2006). These examples illustrate that checkpoint phosphorylation events are counteracted by multiple redundant phosphatases that are regulated themselves in time and space, and, in addition, show regulated activity towards specific substrates.

Protein phosphorylation also controls the extensive ubiquitylation at sites of damage to create a landing platform for additional signalling and repair proteins. The bestcharacterised events are the sequential recruitment of the E3 ubiquitin ligases RNF8 and RNF168 that produce K63-linked polyubiquitin chains (Doil et al., 2009; Stewart et al., 2009), but many other ubiquitin ligases with largely unknown substrates take part in the DDR (Jackson and Durocher, 2013). Several deubiquitylating enzymes (DUBs) have been implicated in removal or editing of the K63 ubiquitin chains formed at DSBs. USP3 and USP44 overexpression reduces the size and number of
DNA damage foci and depletion of POH1, BRCC36 or USP16 results in the defective removal of ubiquitin chains at the site of damage (Butler et al., 2012; Doil et al., 2009; Mosbech et al., 2013; Shanbhag et al., 2010; Shao et al., 2009). Both DUBs $\mathrm{POH} 1$ and BRCC 36 are recruited to K63-linked polyubiquitin chains to reverse these same RNF8- and RNF168-dependent ubiquitylation events at the chromatin, yet their impact on DNA repair processes can be antagonistic, illustrating the complexity of regulation of ubiquitin at DSBs (Butler et al., 2012; Kakarougkas et al., 2013; Shao et al., 2009). Recently, a systematic screen of DUBs identified an additional 29 DUBs that localise to DNA damage when overexpressed as GFP fusions and potentially regulate checkpoint silencing (Nishi et al., 2014).

\section{Removal of modified proteins}

Direct reversal of protein modifications is not the only means to dismantle the DDR. Proteasomal destruction is the end point of many of the modified proteins. The proteasome is recruited to sites of DNA damage, possibly by the associated DUBs POH1 or UCHL5 (Blickwedehl et al., 2007; Butler et al., 2012; Nishi et al., 
2014). The ubiquitin-ligase RNF4 recognizes SUMOylated MDC1 and RPA1 at DNA repair foci and promotes their proteasomal degradation (Galanty et al., 2012). RNF8 not only facilitates the formation of K63-linked polyubiquitin chains by RNF168, but also targets $\mathrm{Ku}$ and $\mathrm{Chk} 2$ for proteasomal degradation via distinct K48-linked ubiquitin chains (Feng and Chen, 2012). Similarly, the E3-ligase Iduna is recruited to and activated by PAR chains, where it targets the PAR polymerase for proteasomal degradation (Kang et al., 2011). Alternatively, eviction and replacement of heavily modified nucleosomes might also aid in terminating checkpoint signals (see Box 2).

\section{Consequences for recovery}

As PTMs are central to both the coordination of DNA repair and checkpoint signalling, disruption of enzymes that remove such PTMs can affect cell survival after DNA damage in multiple ways. Disruption of PP2A activity impairs DSB repair, and the observed persistence of $\gamma \mathrm{H} 2 \mathrm{AX}$ in PP2A-depleted or -inhibited cells might therefore be caused by persistence of DSBs, lack of checkpoint silencing or both (Chen et al., 2014; Chowdhury et al., 2005). Chemical inhibitors of checkpoint kinases, such as caffeine, present a useful tool to separate defects in DNA repair from defects in terminating the checkpoint downstream of these kinases (Davies et al., 2004; van Vugt et al., 2005). In contrast to PP2A, loss of Wip1 or PP4 have limited effects on DSB repair, but strongly affect checkpoint silencing, cell cycle restart and survival after DNA damage, even in the presence of checkpoint kinase inhibitors (Lindqvist et al., 2009a; Moon et al., 2010; Nakada et al., 2008; Shaltiel et al., 2014). Crucial functions of these phosphatases in checkpoint reversal are limited to a select number of substrates, possibly owing to the extensive redundancy

\section{Box 2. Restoring chromatin}

During the DDR, chromatin is extensively remodelled and nucleosomes are removed at the sites of damage (Price and D'Andrea, 2013). The histone chaperone FACT (for 'facilitates chromatin transcription') removes $\gamma \mathrm{H} 2 \mathrm{AX}-\mathrm{H} 2 \mathrm{~B}$ dimers from sites of damage, which is inhibited by PARylation of FACT (Heo et al., 2008). At the same time, FACT is bound to the $E 3$ ubiquitin ligase RNF20 that mono-ubiquitylates histone H2B (Oliveira et al., 2014). Once repair is finished, nucleosomal organisation must be restored to reinstate proper chromatin structure and function (Polo, 2014). Histone chaperones are key players during the restoration of the chromatin. Studies in yeast have shown that reloading of H3K56acetylated histones into repaired DNA requires the histone chaperones Asf1 and CAF-1, which then function as a 'repair complete' signal (Chen et al., 2008; Kim and Haber, 2009). Conflicting reports exist as to whether $\mathrm{H} 3 \mathrm{~K} 56$ acetylation in human cells localises to sites of damage or is removed, although reestablishment of H3K56-acetylated histones is required for recovery from UV-induced DNA lesions (Battu et al., 2011; Das et al., 2009; Miller et al., 2010). In addition, the histone chaperone HIRA has been implicated in restoring the chromatin after UVinduced lesions, where it promotes transcription restart by promoting the insertion of the $\mathrm{H} 3.3$ histone variant (Adam et al., 2013). The observation that HIRA-dependent incorporation of $\mathrm{H} 3.3$ increases after DSBs to promote HR suggests that this is a more general mechanism (Yang et al., 2013). The contribution of these events to the coupling of ongoing repair with reactivation of the cell cycle machinery remains one of the most crucial issues to be resolved in the field. between phosphatases. Wip1 dephosphorylates $\gamma \mathrm{H} 2 \mathrm{AX}$, ATM, p53, Mdm2, Chk1 and Chk2 to repress the DDR (Fujimoto et al., 2006; Lu et al., 2007; Lu et al., 2005; Macůrek et al., 2010; Shreeram et al., 2006), yet its role in checkpoint recovery is restricted to G2 where it is required to antagonise p53 (Fig. 3) (Lindqvist et al., 2009a). Wip1-depletion in p53-deficient cells does not affect recovery from DNA damage in G2, underscoring that Wip1 activity towards these other substrates is dispensable (Lindqvist et al., 2009a). Similarly, PP4 dephosphorylates $\gamma \mathrm{H} 2 \mathrm{AX}, \mathrm{RPA} 2,53 \mathrm{BP} 1, \mathrm{CHD} 4$ and KAP1, but recovery in its absence is mostly affected in G1 cells (Fig. 3), and can be effectively overcome by expression of a non-phosphorylatable mutant of KAP1 (S473A) (Lee et al., 2012; Shaltiel et al., 2014).

Although several DUBs are required for both DNA repair and cell viability after irradiation (Delgado-Díaz et al., 2014; Ismail et al., 2014; Lancini et al., 2014; Nishi et al., 2014), the role of DUBs in checkpoint silencing and cell cycle restart after DNA damage remains to be addressed. Of the 32 DUBs found to localise to sites of DNA damage, 13 appear to be dispensable for overall DNA repair, as judged by single-cell gel electrophoresis, with depletion of USP4, USP37 or POH1 affecting checkpoint kinase signalling. Their contribution to checkpoint silencing needs to be assessed and mapped to relevant substrates.

\section{G2 checkpoint recovery - PIk1 couples cell cycle restart to checkpoint deactivation}

Checkpoint recovery follows largely the same activation pathway as unperturbed mitotic entry (Lindqvist et al., 2009b), but there are clear differences: the DDR inhibits the activities of the promitotic kinases Cdk1, Aurora A and Plk1 (Krystyniak et al., 2005; Lock and Ross, 1990; Smits et al., 2000), and causes the degradation of several proteins that promote mitotic entry, such as Cdc25A and Bora (Falck et al., 2001; Qin et al., 2013). The resultant rewiring of the cell cycle machinery is most clearly demonstrated by the acquired dependence on Plk1 activity for G2 checkpoint recovery (Fig. 3). Plk1 is dispensable for normal mitotic entry and its inhibition in unperturbed cells merely leads to a delay in mitotic entry. However, after a DNA-damageinduced G2 arrest, Plk1 and its upstream activators Aurora A and Bora become essential for re-entry into the cell cycle, by contributing to the activation of cyclin-B1-Cdk1 (Lindqvist et al., 2009b; Macůrek et al., 2008; van Vugt et al., 2004). In parallel, the degradation of $\mathrm{Cdc} 25 \mathrm{~A}$ reduces the redundancy of $\mathrm{Cdc} 25$ phosphatases normally observed during mitotic entry, and recovering cells become dependent on a specific isoform of Cdc25B, which is stabilised after damage (Jullien et al., 2011; van Vugt et al., 2004).

Aside from its roles in re-activation of cyclin-B1-Cdk1, Plk1 additionally controls silencing of DDR signals. The same mechanisms that enable Plk1 to prevent checkpoint signalling in mitosis operate during checkpoint recovery in G2 (Figs 1 and 3). Plk1 activity starts to rise in G2, several hours before mitosis, and at early stages of the DNA damage response Plk1 facilitates strand invasion for HR (Yata et al., 2014). During checkpoint recovery, Plk1 targets claspin for degradation, disabling Chk1 activation (Mailand et al., 2006; Mamely et al., 2006; Peschiaroli et al., 2006). Failure to degrade claspin leads to enhanced and continued Chk1 activity and inability to recover from a G2 arrest. Similarly, Plk1 negatively regulates 53BP1 and Chk2 to promote recovery (van Vugt et al., 2010; Vidanes et al., 2010). Plk1 might also contribute to the inactivation of p53 through direct and indirect mechanisms (Ando et al., 2004; Dias et al., 2009; Liu 


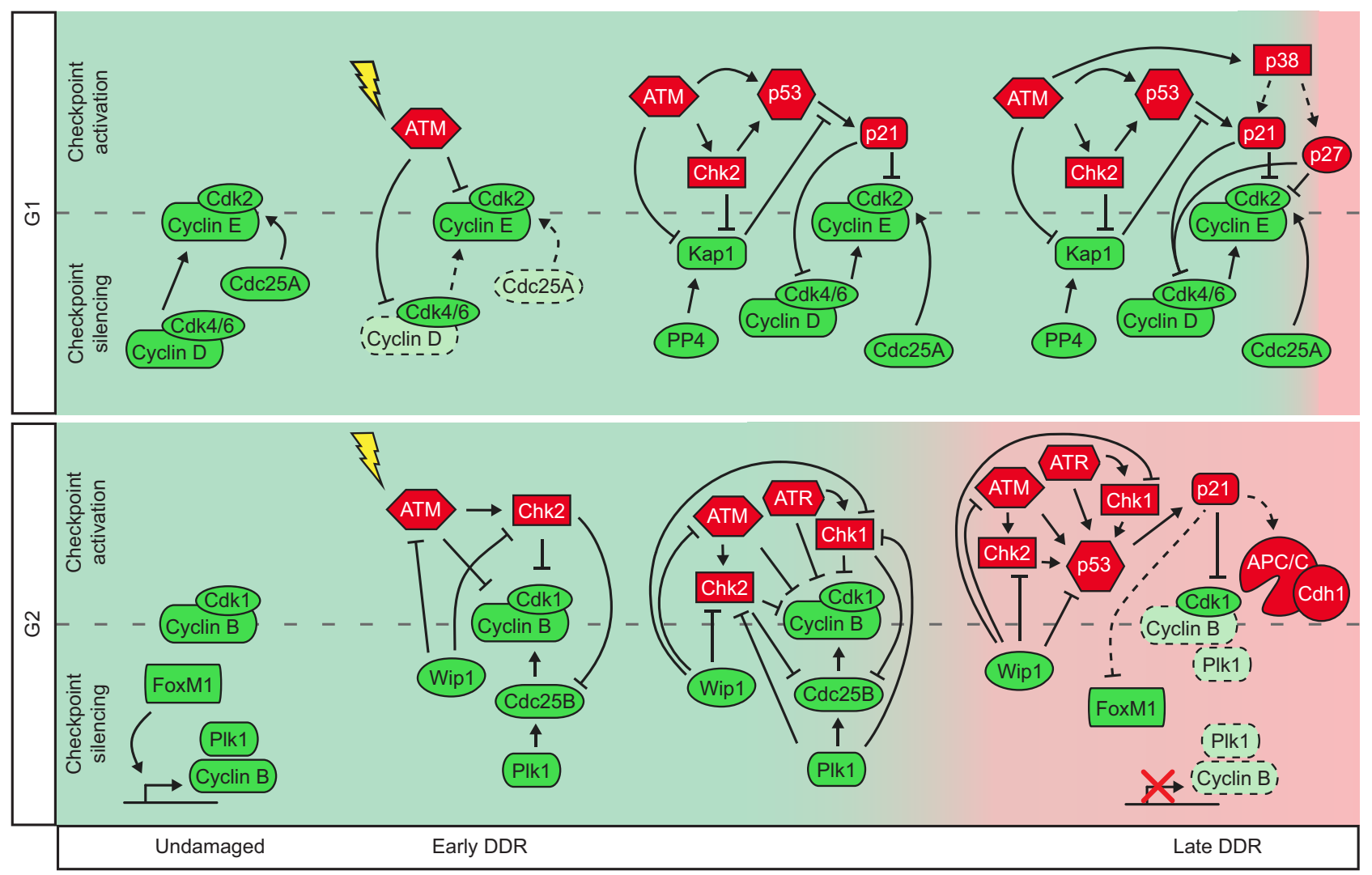

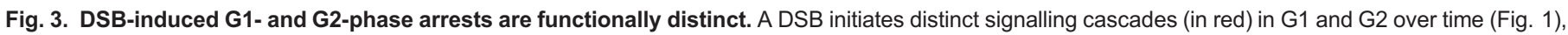

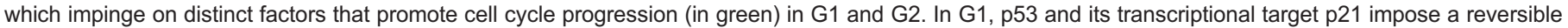
cell cycle arrest by preventing the accumulation of cyclin-E-Cdk2 activity. In G2, signalling by checkpoint kinases inactivates cyclin-B1-Cdk1, reversibly forestalling mitotic progression. As a consequence, recovery from a G1 checkpoint arrest requires PP4-dependent reactivation of KAP1 to turn off p21 transcription, whereas G2 recovery requires Wip1- and Plk1-mediated inhibition of checkpoint kinases and reactivation of cyclin-B1-Cdk1. Because p21-

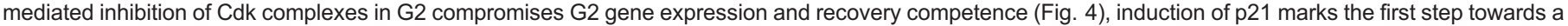
permanent G2 arrest. In sharp contrast, p21 induction in G1 is central to a reversible cell cycle arrest, resulting in very different time windows of checkpoint reversibility (indicated by green background shading) in G1 and G2.

et al., 2010; Yang et al., 2009), and proteomic approaches have identified many potential new binding partners and substrates of Plk1, including DNA damage checkpoint and repair proteins (Halim et al., 2013; Lowery et al., 2007). Plk1 thus drives transitions from arrest to cell cycle re-entry and from checkpoint signalling to checkpoint silencing and recovery.

\section{Adapt now, repair and recover later}

It is typically thought that cell cycle resumption upon a DSBinduced arrest occurs only following completion of DNA repair. However, cells can terminate the checkpoint and enter mitosis in the presence of DNA damage, a process well characterised in unicellular yeast and known as checkpoint adaptation (reviewed in Paulovich et al., 1997). The first hints of checkpoint adaptation in human cells came from the discovery that DNA damage in HCT116 cells resulted in aberrant mitoses (Andreassen et al., 2001), which was later strengthened by the finding that, as in yeast, checkpoint adaptation in human cells requires Plk1 (Syljuåsen et al., 2006; Toczyski et al., 1997). Plk1 must be degraded following DNA damage in order to achieve a proper G2 arrest (Bassermann et al., 2008) and the inability to silence Plk1 activity following DNA damage increases the fraction of cells that is able to enter mitosis (Smits et al., 2000). It was subsequently shown that irradiation of cells in G2 results in increased amounts of $\gamma \mathrm{H} 2 \mathrm{AX}$ and MDC1 foci in mitotic cells, both markers for DNA damage (Deckbar et al., 2007; Kato et al., 2009; Liang et al., 2014), strengthening the notion that maintaining a G2 cell cycle arrest requires a threshold of persistent DNA damage. Using a fluorescence-based probe for Plk1 activity and DNA damage in single cells, Liang and colleagues have recently reported that DNA damage permits a gradual increase of Plk1 activity throughout the arrest (Liang et al., 2014). Once Plk1 activity increases beyond a certain level, the cell progresses to mitosis, regardless of whether DNA damage persists. G2 checkpoint recovery might thus represent checkpoint adaptation, where DNA damage triggers an arrest whose duration is not necessarily conditioned by DNA repair. In support of this notion, the kinetics of recovery from DSBs in G2 in non-transformed cell lines and the mouse intestinal epithelium in vivo indeed show relatively synchronous mitotic entry after a delay of several hours (Chwalinski and Potten, 1986; Shaltiel et al., 2014). However, it is important to note that the inducible expression of a constitutively active mutant of Plk1 (T210D) fails to override an established DNA damage checkpoint (R.H.M., unpublished results), indicating that Plk1 activity is insufficient to drive mitotic entry of cells with a fully activated DDR. Therefore, other factors that contribute to the silencing of the DNA damage 
A
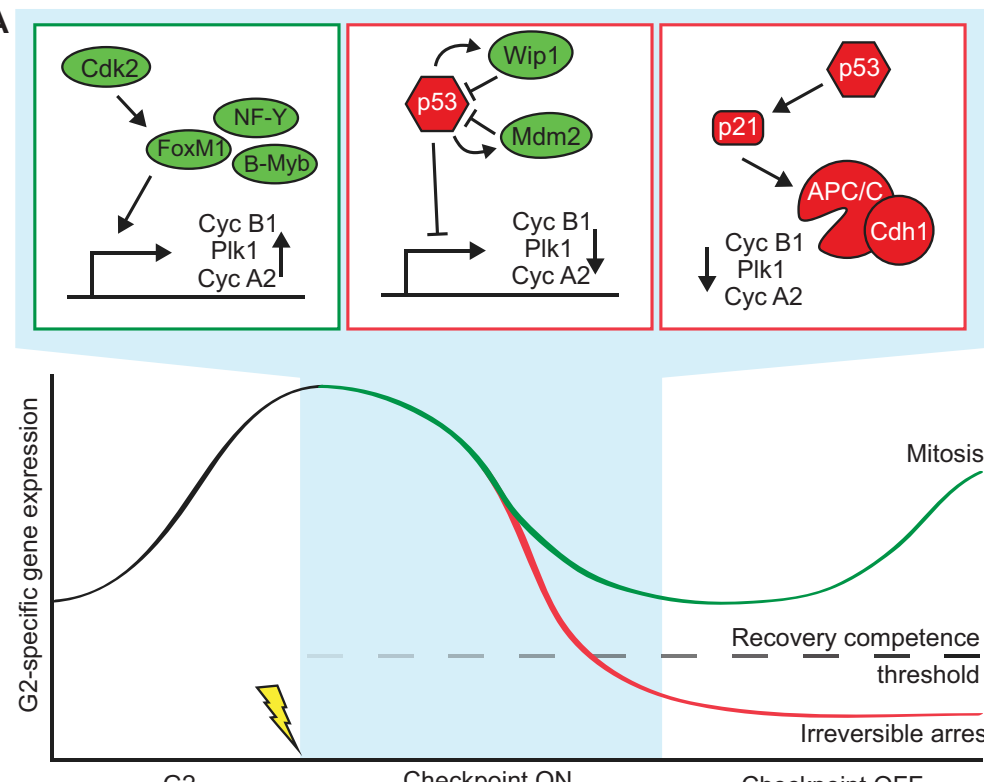

G2

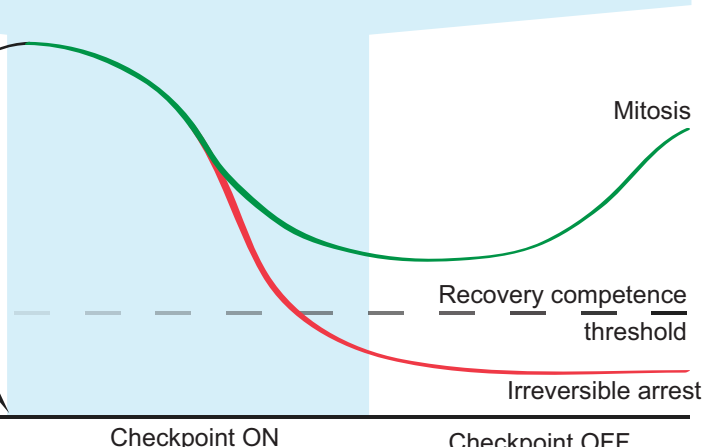

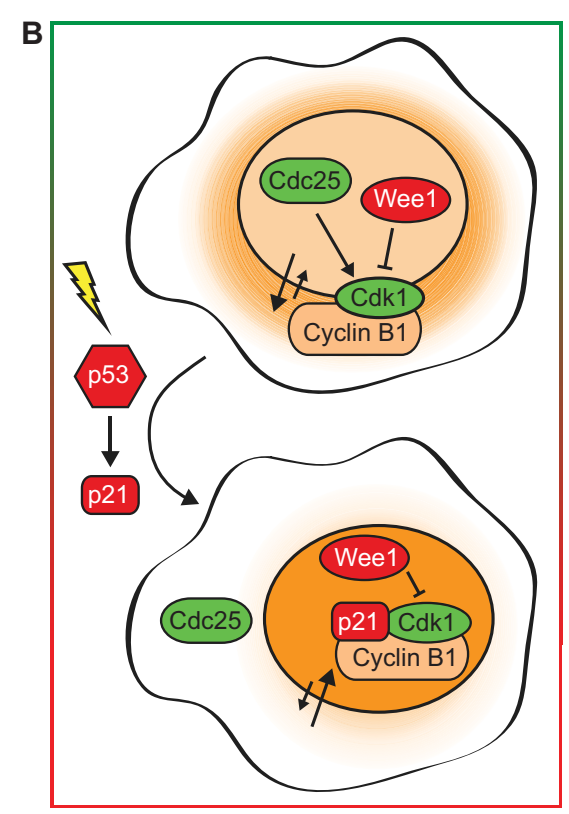

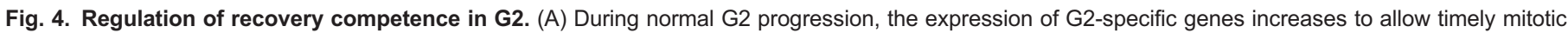
entry. Expression of these genes is dependent on Cdk2. Following DNA damage, reversibility of a G2 arrest requires the sustained expression of G2specific genes, which allows mitotic entry once the checkpoint is silenced. Failure to sustain expression of these genes results in an irreversible $\mathrm{G} 2$ arrest

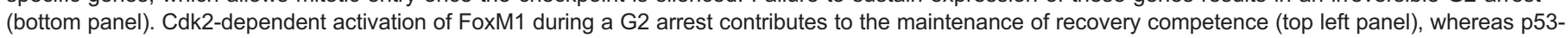
dependent repression of gene expression negatively regulates recovery competence (top middle panel). Wip1 and Mdm2, both negative regulators of p53,

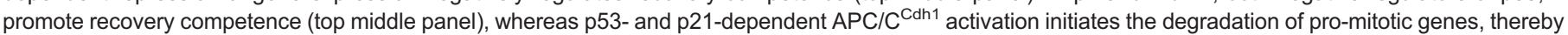

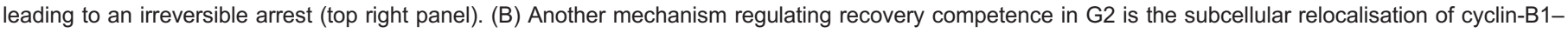
Cdk1 complexes following DNA damage. After DNA damage, cyclin-B1-Cdk1 binds to p21, resulting in its nuclear accumulation. At the same time, Cdc25

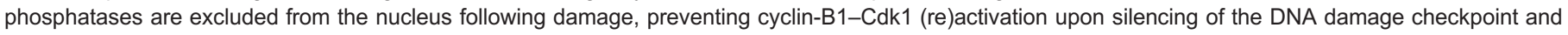
recovery from a G2 arrest.

response operate in conjunction with Plk1 to drive checkpoint recovery or adaptation.

Checkpoint adaptation is a potentially dangerous process, as the propagation of damaged DNA can contribute to tumorigenesis. Mitotic entry in the presence of severe DNA damage results in cell death through mitotic catastrophe (Bunz et al., 1998; Chan et al., 1999; Chen et al., 2003). Alternatively, pre-marked breaks present in G2 cells are partially disassembled during mitosis and carried over to daughter cells where the DDR is fully (re)activated in G1 (Giunta et al., 2010; Lee et al., 2014). Activation of the DDR in G2 can even prime adapting cells for a cell cycle arrest or delay in G1. It has been recently shown that the amount of residual Cdk2 activity at mitotic exit dictates the quiescence or proliferation decision in daughter cells (Spencer et al., 2013). Although cells normally retain some cyclin-E-Cdk2 activity as they complete mitosis and swiftly progress through G1 without the requirement for mitogenic stimulation, the induction of p21 in late $\mathrm{G} 2$ or mitosis gives rise to quiescent daughters with hypophosphorylated retinoblastoma protein (pRb) (Spencer et al., 2013). Similarly, PP2A-B56 $\gamma$-dependent dephosphorylation of $\mathrm{pRb}$ in $\mathrm{G} 2$ results in quiescent daughter cells that lack residual Cdk2 activity (Naetar et al., 2014). Inhibition of PP2A-B56 $\gamma$ in G2 results in increased levels of cyclin E1 in mitotic cells and accelerates Cdk2-dependent S-phase entry in daughter cells. As ATM contributes to the activation of PP2A-B56 $\gamma$ (Shouse et al., 2011), ATM might thus synergise with p21 to inhibit Cdk2 activity in checkpoint-adapting cells, which are then programmed to enter a state of quiescence after cell division to safeguard genomic stability.

\section{G2 checkpoint recovery - maintaining reversibility Balancing pro-mitotic gene expression}

Expression of G2-specific genes is driven by the transcription factors FoxM1, B-Myb (also known as MYBL2) and nuclear factor $\mathrm{Y}$ (NF-Y), and is essential for timely mitotic entry and proper progression through mitosis (Chae et al., 2004; Down et al., 2012; Laoukili et al., 2005). FoxM1, NF-Y and B-Myb are all activated by $\mathrm{Cdk} 2$, ensuring that they become active only when cells progress through S- and G2-phase (Chae et al., 2004; Laoukili et al., 2008; Major et al., 2004; Ziebold et al., 1997). Given that Cdk-activity is required for the transcription of G2-specific genes, decreased Cdk-activity following DNA damage can compromise their expression (Badie et al., 2000; Crawford and Piwnica-Worms, 2001; Maity et al., 1996). Some residual Cdk-activity, possibly supported by specific Cdc25B isoforms (Jullien et al., 2011), must therefore be retained. Temporary elimination of this residual $\mathrm{Cdk}$ activity with inhibitor compounds abolishes G2-specific gene expression and compromises the ability of cells to recover after checkpoint inhibition (Alvarez-Fernández et al., 2010). Similarly, small interfering RNA (siRNA)-mediated depletion of FoxM1 is detrimental to $\mathrm{G} 2$ recovery and can only be rescued by inducible siRNA-resistant FoxM1 when it is present throughout the arrest (Alvarez-Fernández et al., 2010). In conjunction with FoxM1, BMyb contributes to the expression of G2-specific genes during an arrest in G2 and is required for checkpoint recovery in p53deficient cells (Mannefeld et al., 2009). Damaged G2 cells must thus carefully suppress the Cdk-driven G2 transcriptional programme during the arrest to prevent premature mitotic entry, but at the same time retain sufficient expression to maintain 
recovery competence (Fig. 4A; for a review on fine-tuning of transcriptional regulation during a DNA damage-induced G2 arrest see Alvarez-Fernández and Medema, 2010).

p53 counteracts the transcription of many G2-specific genes to contribute to the maintenance of a G2 arrest, and upregulation of p53 is sufficient to permanently arrest cells in G2, even in the absence of DNA damage (Agarwal et al., 1995; Bunz et al., 1998; Krenning et al., 2014; Mannefeld et al., 2009; Riley et al., 2008). Consequently, cells must also balance p53 activity to maintain the reversibility of a G2 arrest (Fig. 4A). This requires negative regulation of $\mathrm{p} 53$ by $\mathrm{Mdm} 2$ and Wip1, which are both transcriptional targets of p53 (Barak et al., 1993; Fiscella et al., 1997). Mdm2 is the main E3 ubiquitin ligase that targets p53 for proteasomal degradation and inhibits its function as a transcription factor (for a review on Mdm2 and p53, see Wade et al., 2013), whereas Wip1 dephosphorylates both p53 and Mdm2 to promote p53 degradation (Lu et al., 2005; Lu et al., 2007). Recently, TRIM24 was identified as an additional p53induced ubiquitin ligase that preferentially targets phosphorylated variants of p53 for degradation (Jain et al., 2014). As a result, p53 levels oscillate in response to DNA damage and altering the oscillatory pattern of p53 results in distinct cell fate outcomes (Batchelor et al., 2008; Lahav et al., 2004; Purvis et al., 2012). Wip1 depletion results in excessive p53 signalling after DNA damage and renders cells unable to recover even when the checkpoint is silenced (Batchelor et al., 2008; Lindqvist et al., 2009a). Reintroducing siRNA-resistant Wip1 restores recovery competence when it is continuously present during the arrest, but not when it is only induced from the moment of checkpoint silencing, underscoring the importance of negative regulation of p53 in the time frame preceding checkpoint reversal for controlling the outcome of the DNA damage response (Lindqvist et al., 2009a).

\section{Degradation of cell cycle proteins regulates recovery competence}

The anaphase-promoting complex/cyclosome (APC/C) is a multiprotein complex with E3 ubiquitin ligase activity that is normally active from the completion of chromosome alignment in mitosis until the end of G1; it is necessary to direct the degradation of cyclins, securin and several mitotic kinases for the orderly completion of mitosis (Primorac and Musacchio, 2013). Two coactivators, $\mathrm{Cdc} 20$ and $\mathrm{Cdh} 1$, sequentially activate the $\mathrm{APC} / \mathrm{C}$. $\mathrm{Cdc} 20$ activates the $\mathrm{APC} / \mathrm{C}$ following chromosome alignment and is inhibited by the spindle assembly checkpoint. This initiates the destruction of cyclin B1 and a decrease in Cdk activity, which is required to allow Cdh1-dependent activation of the $\mathrm{APC} / \mathrm{C}$ during the late stages of mitosis and throughout G1. DNA damage in G2 can activate $\mathrm{APC} / \mathrm{C}^{\mathrm{Cdh} 1}$, which is essential for a persistent $\mathrm{G} 2$ arrest and requires $\mathrm{p} 53$ - and $\mathrm{p} 21$-dependent $\mathrm{Cdk}$ inhibition (Bassermann et al., 2008; Lee et al., 2009; Sudo et al., 2001; Wiebusch and Hagemeier, 2010). Premature activation of the $\mathrm{APC} / \mathrm{C}^{\mathrm{Cdh} 1}$ in $\mathrm{G} 2$ by DNA damage targets many proteins required for mitotic entry for destruction, including cyclin A, cyclin B1 and Plk1, thus preventing recovery from a G2 arrest (Fig. 4A) (Johmura et al., 2014; Krenning et al., 2014; Lee et al., 2009; Lindqvist et al., 2009b; Wiebusch and Hagemeier, 2010). The resulting cells that have a G2 DNA content but lack G2-specific protein expression are committed to senescence (Johmura et al., 2014; Ye et al., 2013). In order for a G2 arrest to remain reversible, Cdk activity must thus be maintained at sufficient levels to preserve pro-mitotic gene transcription, but also to prevent premature activation of the $\mathrm{APC} / \mathrm{C}$.
Subcellular redistribution of proteins as a mechanism to control recovery competence

Throughout G2, cyclin B1 continuously shuttles between the cytoplasm and the nucleus, but the rate of export exceeds the rate of import, resulting in a mostly cytoplasmic localisation until the onset of mitosis (Hagting et al., 1998). In response to DNA damage, cyclin B1 is bound by p21 and relocates to the nucleus within 5 hours in normal human fibroblasts (Charrier-Savournin et al., 2004; Krenning et al., 2014). The binding of p21 to cyclinB1-Cdk1 complexes in the nucleus most likely prevents their nuclear export. Whereas Cdc25A is degraded upon DNA damage, $\mathrm{Cdc} 25 \mathrm{~B}$ and $\mathrm{Cdc} 25 \mathrm{C}$ are exported out of the nucleus (reviewed by Boutros et al., 2006), separating them from cyclin-B1-Cdk1 complexes that have translocated to the nucleus in response to damage. These nuclear p21-bound cyclin-B1-Cdk1 complexes are inhibited by nuclear Wee1 (Charrier-Savournin et al., 2004; Krenning et al., 2014; Müllers et al., 2014). Moreover, once cyclin-B1-Cdk1 complexes have translocated to the nucleus, they become refractory to reactivation by addition of a Wee1 inhibitor, most likely due to the cytoplasmic sequestration of the remaining Cdc25 isoforms. This causes the G2 arrest to be maintained in cells with nuclear cyclin B1, even if the checkpoint is silenced prior to APC/C activation (Fig. 4B) (Charrier-Savournin et al., 2004; Krenning et al., 2014; Müllers et al., 2014). As p53 plays a central role in the nuclear translocation of cyclin B1, APC/C activation and the regulation of repression of pro-mitotic gene transcription, these mechanisms are often attenuated in cancer cells.

\section{G1 checkpoint recovery}

The G1 checkpoint is important in cells that encounter DSBs during G1, as well as those that have adapted from the G2 checkpoint or sustained breaks during mitosis (Giunta et al., 2010). In addition, G2-arrested cells that activate $\mathrm{APC} / \mathrm{C}^{\mathrm{Cdh} 1}$ are likely to be subjected to a G1-type DDR, owing to the lack of Cdk1/2 activity. Reversal of the G1 DNA damage checkpoint appears to be distinct from G2 as, firstly, the crucial players that promote checkpoint recovery in G2 are absent (Plk1 and Cdc25B) or do not affect recovery in G1 (Wip1; Shaltiel et al., 2014). Secondly, unlike the G2 checkpoint, the G1 checkpoint remains reversible for several days in untransformed cells and the mechanisms that cause an irreversible arrest in G2 (Fig. 4) are not relevant in G1 (Deckbar et al., 2010; Krenning et al., 2014; Shaltiel et al., 2014).

Given the exquisite dependence of the G1 checkpoint on p53 and $\mathrm{p} 21$, the oscillatory behaviour of p53 in response to DSBs provides an attractive model of 'recurrent initiation', in which waves of ATM activity, p53 and p21 come and go until triggers (DSBs) are eliminated (Batchelor et al., 2009). The simple take on this model is that activation of the DDR in G1 drives the cell into a quiescent-like state and, as time progresses, the DNA damage can be repaired in order for cells to re-enter G1. In the arrested state, either the DNA damage is repaired in time to drive the cell back to 'early G1', or the intensity and number of pulses commit the cell to an irreversible arrest. Reality, however, appears to be more complex.

First, late signalling events uncouple G1 checkpoint maintenance from ATM activity. This is illustrated by the fact that in the absence of Wip1, ATM activity, gauged by its autophosphorylation, no longer follows a pulsatile pattern, yet p53 oscillations are maintained and G1 checkpoint recovery is unaffected (Batchelor et al., 2008; Shaltiel et al., 2014). This 
suggests that recurrent initiation at the level of the DSB-sensing kinase ATM is not required for the reversibility of the G1 checkpoint. Strikingly, although ATM inhibitors can prevent the initiation of a G1 checkpoint arrest, ATM inhibition is insufficient to reverse the checkpoint arrest (Shaltiel et al., 2014). Instead, G1 checkpoint maintenance relies strongly on the ATM downstream targets Chk2 and p38 MAPK (Deckbar et al., 2010; Lafarga et al., 2009; Raman et al., 2007; Shaltiel et al., 2014). Both kinases can stabilise $\mathrm{p} 53$, and $\mathrm{p} 38$ further contributes to a G1 arrest by stabilising p21-encoding mRNA and p27 (also known as CDKN1B) protein (Cuadrado et al., 2009; Lafarga et al., 2009). It is currently unknown how p38 is controlled after its initial ATM-dependent activation, although the p53 target Gadd $45 \alpha$ has been implicated in maintaining its activity during a persistent arrest (Reinhardt et al., 2010). ATM thus triggers the arrest in response to DSBs in G1, but Chk2 and p38 take over to sustain the arrest independently from ATM. Chk2 and p38 must therefore be silenced to promote a cell cycle restart. Despite the ability of Wip1 to remove the activating phosphorylations on both Chk2 and p38, spontaneous recovery from a G1 checkpoint arrest excludes a major role for Wip1 in terminating Chk2 and p38 signalling (Fujimoto et al., 2006; Shaltiel et al., 2014; Takekawa et al., 2000).

Second, p53 levels do not correlate directly with its transcriptional activity or with the subset of target genes it activates. Target genes are individually regulated by damage signals and other pathways on the levels of DNA, RNA and protein, thereby allowing control beyond p53 dynamics. This is clearly illustrated by $\mathrm{p} 21$, whose transcription is quickly terminated by binding of the co-repressor KAP1 to its promoter, allowing p21 mRNA levels to closely follow the activity of p53 (Gomes and Espinosa, 2010; Lee et al., 2007; Purvis et al., 2012). KAP1 itself is inhibited by ATM- and Chk1- or Chk2-mediated phosphorylation, which is counteracted by the PP4 phosphatase (Lee et al., 2012; Li et al., 2007; White et al., 2012). Tampering with the dynamic repression of p21 transcription by depleting either KAP1 itself or PP4 compromises G1 checkpoint reversal, making KAP1 and PP4 essential for G1 checkpoint recovery (Shaltiel et al., 2014). At the mRNA level, p21 transcripts must be stabilised by the RNAbinding protein $\mathrm{HuR}$, which requires $\mathrm{HuR}$ to be phosphorylated by Chk2 and/or p38 (Abdelmohsen et al., 2007; Lafarga et al., 2009). Thus, whereas p53 remains a prerequisite for $\mathrm{p} 21$ induction in response to DNA damage, several pathways converge on its targets to define the reversibility of the arrest.

\section{What determines cellular fate?}

Although the regulation of recovery competence is quite well understood, little is known about factors that determine whether a cell will remain recovery competent or exit the cell cycle upon DNA damage. As many of the processes regulating recovery competence are affected by $\mathrm{p} 53$, cell fate decisions will most likely be made at the level of p53. Indeed, a permanent cell cycle exit in G2 requires p53 (Bunz et al., 1998; Johmura et al., 2014; Krenning et al., 2014), and cells depleted of p53 are unable to maintain a stable G2 arrest and eventually will progress through mitosis in the presence of DNA damage (Bunz et al., 1998).

Recovery competence is much more stringently regulated in G2 compared to G1 phase. Whereas an 8-hour pulse of p53 activation readily induces senescence in G2 cells, it fails to do so in G1 (Krenning et al., 2014; R.H.M., unpublished results), indicating that the cell cycle position of a DNA-damaged cell influences recovery competence. In addition, the mode of p53 activation greatly impacts upon cell fate decisions (Purvis et al., 2012). One factor that affects p53 activation and cellular outcome is the amount of DNA damage, where increasing doses of DSBs result in a stronger activation of $\mathrm{p} 53$ and cause more cells to become senescent (Loewer et al., 2013; Purvis et al., 2012). Furthermore, sustained DSBs cause the continuous oscillation of p53, resulting in an increased induction of p21 and a greater propensity to enter senescence (Lahav et al., 2004; Loewer et al., 2013; Loewer et al., 2010). However, recent data show that cell fate decisions in DNA-damaged G2 cells are established within 5 hours, which would correspond to the first wave of p53 (Krenning et al., 2014). This suggests that the strength of the first p53 oscillation, rather than number of oscillations, establishes cellular fate in G2. These observations, albeit contradictory, might very well operate within the same cell. Although DNA-damaged G1 cells retain recovery competence longer than their G2 counterparts, they eventually become incapable of G1 recovery (R.H.M., unpublished results). It is likely that G1 recovery competence is dictated by the number of p53 oscillations, whereas G2 recovery competence is determined by the strength of the first pulse. Another explanation for these contradictory observations might be found in the cell types used for investigation. Much of the knowledge obtained about p53 oscillations comes from transformed cell lines, in which the mechanisms for cell cycle exit are often repressed (Bulavin et al., 2002; Kleiblova et al., 2013; Müllers et al., 2014). Clearly, p53 activity is a major determinant in cellular fate decisions; however, how regulation upstream or downstream of p53 affects cellular fate remains largely unresolved.

In addition, the location of DNA damage might greatly influence the outcome of a DNA damaging insult. Up to half of the persistent DNA damage foci in cells undergoing senescence in response to ionising radiation are associated with telomeres (Hewitt et al., 2012). This telomeric DNA damage is refractory to repair and as a result causes persistent DNA damage signalling (Fumagalli et al., 2012; Noda et al., 2012). Indeed, p53oscillations might be different in cells with similar amount of DNA damage foci (Loewer et al., 2013), indicating that the location of DNA damage, or its type or repair state, might influence p53 dynamics. As not all persistent foci in irradiationinduced senescence are found at telomeres, this raises the question as to whether there are other genomic loci that are refractory to DNA repair, but instead will activate persistent DNA damage signalling and the onset of senescence.

\section{Conclusion and future directions}

DNA damage checkpoint arrests are useful as long as they can be reversed when appropriate. The notion that recovery from a DNA-damage-induced arrest is merely a consequence of DNA repair is out-dated: checkpoint recovery involves the timely and spatially controlled action of numerous enzymes that disassemble DNA damage foci as the DNA is repaired and an extensive interplay between the cell cycle machinery and DDR that we are only starting to comprehend. In addition, little is known about the determinants of cell fate following a DNA damaging insult. As the first hints of processes underlying cell fate decisions, such as the mode of p53 activation or DNA damage severity (Krenning et al., 2014; Purvis et al., 2012), are being reported, many questions are left unanswered. For instance, it remains to be determined whether the location of a DSB, or the repair pathway used for its repair affect cellular fate. 
Understanding these processes is vital to our understanding of normal cell biology, tumorigenesis and cancer resistance to genotoxic therapy. The accumulation of mutations during tumorigenesis likely requires several events of checkpoint recovery. Consistent with this is the finding that positive regulators of checkpoint recovery in G2 are commonly overexpressed in cancer and associated with poor prognosis (Bulavin et al., 2002; Cholewa et al., 2013; Li et al., 2002; Wang et al., 2008; Wierstra, 2013). Conversely, tumorigenesis is impaired in their absence (Bulavin et al., 2004; Wang et al., 2009), and several regulators of G2 checkpoint recovery are under (pre)clinical evaluation (Gilmartin et al., 2014; Gumireddy et al., 2005; Stadler et al., 2014). Understanding the mechanisms underlying cellular fate will allow us to devise new therapeutic strategies to sensitise cancer cells to DNA-damaging agents currently used in the clinic.

\section{Competing interests}

The authors declare no competing or financial interests.

\section{Funding}

This work was supported by Koningin Wilhelmina Fonds (KWF) [grant number NKI 2009-4478 to R.H.M.]; and Nederlandse Organisatie voor Wetenschappelijk Onderzoek (NWO) [Cancer Genomics Center, CGC.nl to R.H.M., and grant number 022.001 .003 to L.K.].

\section{References}

Abbas, T., Sivaprasad, U., Terai, K., Amador, V., Pagano, M. and Dutta, A. (2008). PCNA-dependent regulation of p21 ubiquitylation and degradation via the CRL4Cdt2 ubiquitin ligase complex. Genes Dev. 22, 2496-2506.

Abdelmohsen, K., Pullmann, R., Jr, Lal, A., Kim, H. H., Galban, S., Yang, X., Blethrow, J. D., Walker, M., Shubert, J., Gillespie, D. A. et al. (2007). Phosphorylation of HuR by Chk2 regulates SIRT1 expression. Mol. Cell 25, 543557.

Adam, S., Polo, S. E. and Almouzni, G. (2013). Transcription recovery after DNA damage requires chromatin priming by the H3.3 histone chaperone HIRA. Cell 155, 94-106.

Agami, R. and Bernards, R. (2000). Distinct initiation and maintenance mechanisms cooperate to induce $\mathrm{G} 1$ cell cycle arrest in response to DNA damage. Cell 102, 55-66.

Agarwal, M. L., Agarwal, A., Taylor, W. R. and Stark, G. R. (1995). p53 controls both the G2/M and the $\mathrm{G} 1$ cell cycle checkpoints and mediates reversible growth arrest in human fibroblasts. Proc. Natl. Acad. Sci. USA 92, 84938497

Alberts, A. S., Thorburn, A. M., Shenolikar, S., Mumby, M. C. and Feramisco, J. R. (1993). Regulation of cell cycle progression and nuclear affinity of the retinoblastoma protein by protein phosphatases. Proc. Natl. Acad. Sci. USA 90, 388-392.

Alvarez-Fernández, M. and Medema, R. H. (2010). A new role for Cdks in the DNA damage response. Cell Cycle 9, 2915-2916.

Alvarez-Fernández, M., Halim, V. A., Krenning, L., Aprelia, M., Mohammed, S., Heck, A. J. and Medema, R. H. (2010). Recovery from a DNA-damage-induced G2 arrest requires Cdk-dependent activation of FoxM1. EMBO Rep. 11, 452458.

Ando, K., Ozaki, T., Yamamoto, H., Furuya, K., Hosoda, M., Hayashi, S., Fukuzawa, M. and Nakagawara, A. (2004). Polo-like kinase 1 (Plk1) inhibits p53 function by physical interaction and phosphorylation. J. Biol. Chem. 279, 25549-25561.

Andreassen, P. R., Lacroix, F. B., Lohez, O. D. and Margolis, R. L. (2001). Neither p21WAF1 nor 14-3-3 $\sigma$ prevents G2 progression to mitotic catastrophe in human colon carcinoma cells after DNA damage, but p21WAF1 induces stable G1 arrest in resulting tetraploid cells. Cancer Res. 61, 7660-7668.

Badie, C., Itzhaki, J. E., Sullivan, M. J., Carpenter, A. J. and Porter, A. C. G. (2000). Repression of CDK1 and other genes with CDE and CHR promoter elements during DNA damage-induced $\mathrm{G}(2) / \mathrm{M}$ arrest in human cells. Mol. Cell. Biol. 20, 2358-2366.

Barak, Y., Juven, T., Haffner, R. and Oren, M. (1993). mdm2 expression is induced by wild type p53 activity. EMBO J. 12, 461-468

Bassermann, F., Frescas, D., Guardavaccaro, D., Busino, L., Peschiaroli, A. and Pagano, M. (2008). The Cdc14B-Cdh1-Plk1 axis controls the G2 DNAdamage-response checkpoint. Cell 134, 256-267.

Batchelor, E., Mock, C. S., Bhan, I., Loewer, A. and Lahav, G. (2008). Recurrent initiation: a mechanism for triggering p53 pulses in response to DNA damage. Mol. Cell 30, 277-289.

Batchelor, E., Loewer, A. and Lahav, G. (2009). The ups and downs of p53: understanding protein dynamics in single cells. Nat. Rev. Cancer 9, 371377.
Battu, A., Ray, A. and Wani, A. A. (2011). ASF1A and ATM regulate H3K56mediated cell-cycle checkpoint recovery in response to UV irradiation. Nucleic Acids Res. 39, 7931-7945.

Beck, H., Nähse, V., Larsen, M. S. Y., Groth, P., Clancy, T., Lees, M., Jørgensen, M., Helleday, T., Syljuåsen, R. G. and Sørensen, C. S. (2010). Regulators of cyclin-dependent kinases are crucial for maintaining genome integrity in S phase. J. Cell Biol. 188, 629-638.

Blickwedehl, J., McEvoy, S., Wong, I., Kousis, P., Clements, J., Elliott, R., Cresswell, P., Liang, P. and Bangia, N. (2007). Proteasomes and proteasome activator $200 \mathrm{kDa}$ (PA200) accumulate on chromatin in response to ionizing radiation. Radiat. Res. 167, 663-674.

Boutros, R., Dozier, C. and Ducommun, B. (2006). The when and wheres of CDC25 phosphatases. Curr. Opin. Cell Biol. 18, 185-191.

Brown, E. J. and Baltimore, D. (2003). Essential and dispensable roles of ATR in cell cycle arrest and genome maintenance. Genes Dev. 17, 615-628.

Buis, J., Stoneham, T., Spehalski, E. and Ferguson, D. O. (2012). Mre11 regulates CtIP-dependent double-strand break repair by interaction with CDK2. Nat. Struct. Mol. Biol. 19, 246-252.

Bulavin, D. V., Demidov, O. N., Saito, S., Kauraniemi, P., Phillips, C., Amundson, S. A., Ambrosino, C., Sauter, G., Nebreda, A. R., Anderson, C. W. et al. (2002). Amplification of PPM1D in human tumors abrogates p53 tumor-suppressor activity. Nat. Genet. 31, 210-215.

Bulavin, D. V., Phillips, C., Nannenga, B., Timofeev, O., Donehower, L. A., Anderson, C. W., Appella, E. and Fornace, A. J., Jr (2004). Inactivation of the Wip1 phosphatase inhibits mammary tumorigenesis through p38 MAPKmediated activation of the p16(Ink4a)-p19(Arf) pathway. Nat. Genet. 36, 343350.

Bunz, F., Dutriaux, A., Lengauer, C., Waldman, T., Zhou, S., Brown, J. P., Sedivy, J. M., Kinzler, K. W. and Vogelstein, B. (1998). Requirement for p53 and p21 to sustain G2 arrest after DNA damage. Science 282, 1497-1501.

Burma, S., Chen, B. P., Murphy, M., Kurimasa, A. and Chen, D. J. (2001). ATM phosphorylates histone $\mathrm{H} 2 \mathrm{AX}$ in response to DNA double-strand breaks. J. Biol. Chem. 276, 42462-42467.

Butler, L. R., Densham, R. M., Jia, J., Garvin, A. J., Stone, H. R., Shah, V., Weekes, D., Festy, F., Beesley, J. and Morris, J. R. (2012). The proteasomal de-ubiquitinating enzyme $\mathrm{POH} 1$ promotes the double-strand DNA break response. EMBO J. 31, 3918-3934.

Carlessi, L., Buscemi, G., Fontanella, E. and Delia, D. (2010). A protein phosphatase feedback mechanism regulates the basal phosphorylation of Chk2 kinase in the absence of DNA damage. Biochim. Biophys. Acta 1803, 1213-1223.

Chae, H.-D., Yun, J., Bang, Y.-J. and Shin, D. Y. (2004). Cdk2-dependent phosphorylation of the NF-Y transcription factor is essential for the expression of the cell cycle-regulatory genes and cell cycle G1/S and G2/M transitions. Oncogene 23, 4084-4088.

Chan, T. A., Hermeking, H., Lengauer, C., Kinzler, K. W. and Vogelstein, B. (1999). 14-3-3Sigma is required to prevent mitotic catastrophe after DNA damage. Nature 401, 616-620.

Charrier-Savournin, F. B., Château, M.-T., Gire, V., Sedivy, J., Piette, J. and Dulic, V. (2004). p21-Mediated nuclear retention of cyclin B1-Cdk1 in response to genotoxic stress. Mol. Biol. Cell 15, 3965-3976.

Chen, P., Gatei, M., O'Connell, M. J., Khanna, K. K., Bugg, S. J., Hogg, A., Scott, S. P., Hobson, K. and Lavin, M. F. (1999). Chk1 complements the G2/M checkpoint defect and radiosensitivity of ataxia-telangiectasia cells. Oncogene 18, 249-256.

Chen, Z., Xiao, Z., Chen, J., Ng, S.-C., Sowin, T., Sham, H., Rosenberg, S., Fesik, S. and Zhang, H. (2003). Human Chk1 expression is dispensable for somatic cell death and critical for sustaining G2 DNA damage checkpoint. Mol. Cancer Ther. 2, 543-548.

Chen, C.-C., Carson, J. J., Feser, J., Tamburini, B., Zabaronick, S., Linger, J. and Tyler, J. K. (2008). Acetylated lysine 56 on histone H3 drives chromatin assembly after repair and signals for the completion of repair. Cell 134, 231-243.

Chen, L., Lai, Y., Zhu, X., Ma, L., Bai, Q., Vazquez, I., Xiao, Y., Liu, C., Li, D., Gao, C. et al. (2014). The role of specific PP2A complexes in the dephosphorylation of $\gamma-\mathrm{H} 2 \mathrm{AX}$. J. Cell Sci.

Cholewa, B. D., Liu, X. and Ahmad, N. (2013). The role of polo-like kinase 1 in carcinogenesis: cause or consequence? Cancer Res. 73, 6848-6855.

Chow, J. P. H., Siu, W. Y., Ho, H. T., Ma, K. H., Ho, C. C. and Poon, R. Y. (2003). Differential contribution of inhibitory phosphorylation of CDC2 and CDK2 for unperturbed cell cycle control and DNA integrity checkpoints. J. Biol. Chem. 278, 40815-40828.

Chowdhury, D., Keogh, M.-C., Ishii, H., Peterson, C. L., Buratowski, S. and Lieberman, J. (2005). gamma-H2AX dephosphorylation by protein phosphatase 2A facilitates DNA double-strand break repair. Mol. Cell 20, 801809.

Chowdhury, D., Xu, X., Zhong, X., Ahmed, F., Zhong, J., Liao, J., Dykxhoorn, D. M., Weinstock, D. M., Pfeifer, G. P. and Lieberman, J. (2008). A PP4phosphatase complex dephosphorylates gamma-H2AX generated during DNA replication. Mol. Cell 31, 33-46.

Chwalinski, S. and Potten, C. S. (1986). Radiation-induced mitotic delay: duration, dose and cell position dependence in the crypts of the small intestine in the mouse. Int. J. Radiat. Biol. 49, 809-819.

Cicchillitti, L., Fasanaro, P., Biglioli, P., Capogrossi, M. C. and Martelli, F. (2003). Oxidative stress induces protein phosphatase 2A-dependent dephosphorylation of the pocket proteins pRb, p107, and p130. J. Biol. Chem. 278, 19509-19517. 
Ciccia, A. and Elledge, S. J. (2010). The DNA damage response: making it safe to play with knives. Mol. Cell 40, 179-204.

Crawford, D. F. and Piwnica-Worms, H. (2001). The G(2) DNA damage checkpoint delays expression of genes encoding mitotic regulators. J. Biol. Chem. 276, 37166-37177.

Cuadrado, M., Gutierrez-Martinez, P., Swat, A., Nebreda, A. R. and FernandezCapetillo, O. (2009). p27Kip1 stabilization is essential for the maintenance of cell cycle arrest in response to DNA damage. Cancer Res. 69, 87268732.

Das, C., Lucia, M. S., Hansen, K. C. and Tyler, J. K. (2009). CBP/p300-mediated acetylation of histone $\mathrm{H} 3$ on lysine 56 . Nature 459, 113-117.

Davies, S. L., North, P. S., Dart, A., Lakin, N. D. and Hickson, I. D. (2004). Phosphorylation of the Bloom's syndrome helicase and its role in recovery from S-phase arrest. Mol. Cell. Biol. 24, 1279-1291.

Deckbar, D., Birraux, J., Krempler, A., Tchouandong, L., Beucher, A., Walker S., Stiff, T., Jeggo, P. and Löbrich, M. (2007). Chromosome breakage after G2 checkpoint release. J. Cell Biol. 176, 749-755.

Deckbar, D., Stiff, T., Koch, B., Reis, C., Löbrich, M. and Jeggo, P. A. (2010) The limitations of the G1-S checkpoint. Cancer Res. 70, 4412-4421.

Delgado-Díaz, M. R., Martín, Y., Berg, A., Freire, R. and Smits, V. A. J. (2014) Dub3 controls DNA damage signalling by direct deubiquitination of $\mathrm{H} 2 \mathrm{AX}$. Mol Oncol. 8, 884-893.

den Elzen, N. R. and O'Connell, M. J. (2004). Recovery from DNA damage checkpoint arrest by PP1-mediated inhibition of Chk1. EMBO J. 23, 908918.

Deng, C., Zhang, P., Harper, J. W., Elledge, S. J. and Leder, P. (1995). Mice lacking p21CIP1/WAF1 undergo normal development, but are defective in G1 checkpoint control. Cell 82, 675-684.

Deriano, L. and Roth, D. B. (2013). Modernizing the nonhomologous end-joining repertoire: alternative and classical NHEJ share the stage. Annu. Rev. Genet. 47, 433-455.

Dias, S. S., Hogan, C., Ochocka, A.-M. and Meek, D. W. (2009). Polo-like kinase1 phosphorylates MDM2 at Ser260 and stimulates MDM2-mediated p53 turnover. FEBS Lett. 583, 3543-3548.

Doil, C., Mailand, N., Bekker-Jensen, S., Menard, P., Larsen, D. H., Pepperkok, R., Ellenberg, J., Panier, S., Durocher, D., Bartek, J. et al. (2009). RNF168 binds and amplifies ubiquitin conjugates on damaged chromosomes to allow accumulation of repair proteins. Cell 136, 435-446.

Douglas, P., Zhong, J., Ye, R., Moorhead, G. B. G., Xu, X. and Lees-Miller, S. P. (2010). Protein phosphatase 6 interacts with the DNA-dependent protein kinase catalytic subunit and dephosphorylates gamma-H2AX. Mol. Cell. Biol. 30, 13681381

Down, C. F., Millour, J., Lam, E. W. F. and Watson, R. J. (2012). Binding of FoxM1 to G2/M gene promoters is dependent upon B-Myb. Biochim. Biophys. Acta. 1819, 855-862.

Dozier, C., Bonyadi, M., Baricault, L., Tonasso, L. and Darbon, J.-M. (2004). Regulation of Chk2 phosphorylation by interaction with protein phosphatase $2 \mathrm{~A}$ via its B' regulatory subunit. Biol. Cell 96, 509-517.

Falck, J., Mailand, N., Syljuåsen, R. G., Bartek, J. and Lukas, J. (2001). The ATM-Chk2-Cdc25A checkpoint pathway guards against radioresistant DNA synthesis. Nature 410, 842-847.

Feng, L. and Chen, J. (2012). The E3 ligase RNF8 regulates KU80 removal and NHEJ repair. Nat. Struct. Mol. Biol. 19, 201-206.

Fiscella, M., Zhang, H., Fan, S., Sakaguchi, K., Shen, S., Mercer, W. E., Vande Woude, G. F., O'Connor, P. M. and Appella, E. (1997). Wip1, a novel human protein phosphatase that is induced in response to ionizing radiation in a p53dependent manner. Proc. Natl. Acad. Sci. USA 94, 6048-6053.

Floyd, S. R., Pacold, M. E., Huang, Q., Clarke, S. M., Lam, F. C., Cannell, I. G., Bryson, B. D., Rameseder, J., Lee, M. J., Blake, E. J. et al. (2013). The bromodomain protein Brd4 insulates chromatin from DNA damage signalling. Nature 498, 246-250.

Freeman, A. K., Dapic, V. and Monteiro, A. N. A. (2010). Negative regulation of CHK2 activity by protein phosphatase $2 \mathrm{~A}$ is modulated by DNA damage. Cell Cycle 9, 736-747.

Fujimoto, H., Onishi, N., Kato, N., Takekawa, M., Xu, X. Z., Kosugi, A., Kondo, T., Imamura, M., Oishi, I., Yoda, A. et al. (2006). Regulation of the antioncogenic Chk2 kinase by the oncogenic Wip1 phosphatase. Cell Death Differ. 13, 1170-1180.

Fumagalli, M., Rossiello, F., Clerici, M., Barozzi, S., Cittaro, D., Kaplunov, J. M., Bucci, G., Dobreva, M., Matti, V., Beausejour, C. M. et al. (2012). Telomeric DNA damage is irreparable and causes persistent DNA-damage-response activation. Nat. Cell Biol. 14, 355-365.

Galanty, Y., Belotserkovskaya, R., Coates, J. and Jackson, S. P. (2012). RNF4 a SUMO-targeted ubiquitin E3 ligase, promotes DNA double-strand break repair. Genes Dev. 26, 1179-1195.

Gilmartin, A. G., Faitg, T. H., Richter, M., Groy, A., Seefeld, M. A., Darcy, M. G. Peng, X., Federowicz, K., Yang, J., Zhang, S.-Y. et al. (2014). Allosteric Wip1 phosphatase inhibition through flap-subdomain interaction. Nat. Chem. Biol. 10, 181-187.

Giunta, S., Belotserkovskaya, R. and Jackson, S. P. (2010). DNA damage signaling in response to double-strand breaks during mitosis. J. Cell Biol. 190, 197-207.

Gomes, N. P. and Espinosa, J. M. (2010). Disparate chromatin landscapes and kinetics of inactivation impact differential regulation of p53 target genes. Cell Cycle 9, 3428-3437.
Goodarzi, A. A., Jonnalagadda, J. C., Douglas, P., Young, D., Ye, R., Moorhead, G. B. G., Lees-Miller, S. P. and Khanna, K. K. (2004). Autophosphorylation of ataxia-telangiectasia mutated is regulated by protein phosphatase $2 \mathrm{~A}$. EMBO J. 23, 4451-4461.

Gumireddy, K., Reddy, M. V. R., Cosenza, S. C., Boominathan, R., Baker, S. J., Papathi, N., Jiang, J., Holland, J. and Reddy, E. P. (2005). ON01910, a nonATP-competitive small molecule inhibitor of Plk1, is a potent anticancer agent. Cancer Cell 7, 275-286.

Guo, C. Y., Brautigan, D. L. and Larner, J. M. (2002). lonizing radiation activates nuclear protein phosphatase-1 by ATM-dependent dephosphorylation. J. Biol. Chem. 277, 41756-41761.

Hagting, A., Karlsson, C., Clute, P., Jackman, M. and Pines, J. (1998). MPF localization is controlled by nuclear export. EMBO J. 17, 4127-4138.

Halim, V. A., Alvarez-Fernández, M., Xu, Y. J., Aprelia, M., van den Toorn, H. W. P., Heck, A. J. R., Mohammed, S. and Medema, R. H. (2013). Comparative phosphoproteomic analysis of checkpoint recovery identifies new regulators of the DNA damage response. Sci. Signal. 6, rs9-rs9.

Harper, J. W., Adami, G. R., Wei, N., Keyomarsi, K. and Elledge, S. J. (1993). The p21 Cdk-interacting protein Cip1 is a potent inhibitor of G1 cyclin-dependent kinases. Cell 75, 805-816.

Harper, J. W., Elledge, S. J., Keyomarsi, K., Dynlacht, B., Tsai, L. H., Zhang, P., Dobrowolski, S., Bai, C., Connell-Crowley, L., Swindell, E. et al. (1995). Inhibition of cyclin-dependent kinases by p21. Mol. Biol. Cell 6, 387-400.

Havens, C. G. and Walter, J. C. (2011). Mechanism of CRL4(Cdt2), a PCNAdependent E3 ubiquitin ligase. Genes Dev. 25, 1568-1582.

Heo, K., Kim, H., Choi, S. H., Choi, J., Kim, K., Gu, J., Lieber, M. R., Yang, A. S. and An, W. (2008). FACT-mediated exchange of histone variant $\mathrm{H} 2 \mathrm{AX}$ regulated by phosphorylation of H2AX and ADP-ribosylation of Spt16. Mol. Cell 30, 86-97.

Hewitt, G., Jurk, D., Marques, F. D. M., Correia-Melo, C., Hardy, T., Gackowska, A., Anderson, R., Taschuk, M., Mann, J. and Passos, J. F. (2012). Telomeres are favoured targets of a persistent DNA damage response in ageing and stress-induced senescence. Nat. Commun. 3, 708.

Hirai, H., Iwasawa, Y., Okada, M., Arai, T., Nishibata, T., Kobayashi, M., Kimura, T., Kaneko, N., Ohtani, J., Yamanaka, K. et al. (2009). Smallmolecule inhibition of Wee1 kinase by MK-1775 selectively sensitizes p53deficient tumor cells to DNA-damaging agents. Mol. Cancer Ther. 8, 29923000

Hirao, A., Cheung, A., Duncan, G., Girard, P.-M., Elia, A. J., Wakeham, A., Okada, H., Sarkissian, T., Wong, J. A., Sakai, T. et al. (2002). Chk2 is a tumor suppressor that regulates apoptosis in both an ataxia telangiectasia mutated (ATM)-dependent and an ATM-independent manner. Mol. Cell. Biol. 22, 65216532.

Hoeijmakers, J. H. J. (2009). DNA damage, aging, and cancer. N. Engl. J. Med. 361, 1475-1485.

Hughes, B. T., Sidorova, J., Swanger, J., Monnat, R. J., Jr and Clurman, B. E. (2013). Essential role for Cdk2 inhibitory phosphorylation during replication stress revealed by a human Cdk2 knockin mutation. Proc. Natl. Acad. Sci. USA 110, 8954-8959.

Illuzzi, G., Fouquerel, E., Amé, J.-C., Noll, A., Rehmet, K., Nasheuer, H.-P., Dantzer, F. and Schreiber, V. (2014). PARG is dispensable for recovery from transient replicative stress but required to prevent detrimental accumulation of poly(ADP-ribose) upon prolonged replicative stress. Nucleic Acids Res. 42, 7776-7792.

Ira, G., Pellicioli, A., Balijja, A., Wang, X., Fiorani, S., Carotenuto, W., Liberi, G., Bressan, D., Wan, L., Hollingsworth, N. M. et al. (2004). DNA end resection, homologous recombination and DNA damage checkpoint activation require CDK1. Nature 431, 1011-1017.

Ismail, I. H., Davidson, R., Gagne, J. P., Xu, Z. Z., Poirier, G. and Hendzel, M. J. (2014). Germ-line Mutations in BAP1 Impair its Function in DNA Double-Strand break Repair. Cancer Res. 74, 4282-4294.

Jackson, S. P. and Durocher, D. (2013). Regulation of DNA damage responses by ubiquitin and SUMO. Mol. Cell 49, 795-807.

Jain, A. K., Allton, K., Duncan, A. D. and Barton, M. C. (2014). TRIM24 is a p53induced E3-ubiquitin ligase that undergoes ATM-mediated phosphorylation and autodegradation during DNA damage. Mol. Cell. Biol. 34, 2695-2709.

Johmura, Y., Shimada, M., Misaki, T., Naiki-Ito, A., Miyoshi, H., Motoyama, N., Ohtani, N., Hara, E., Nakamura, M., Morita, A. et al. (2014). Necessary and sufficient role for a mitosis skip in senescence induction. Mol. Cell 55, 73-84.

Jullien, D., Bugler, B., Dozier, C., Cazales, M. and Ducommun, B. (2011). Identification of N-terminally truncated stable nuclear isoforms of CDC25B that are specifically involved in G2/M checkpoint recovery. Cancer Res. 71, 19681977.

Kakarougkas, A., Ismail, A., Katsuki, Y., Freire, R., Shibata, A. and Jeggo, P. A. (2013). Co-operation of BRCA1 and $\mathrm{POH} 1$ relieves the barriers posed by 53BP1 and RAP80 to resection. Nucleic Acids Res. 41, 10298-10311.

Kang, Y., Lee, J.-H., Hoan, N. N., Sohn, H.-M., Chang, I.-Y. and You, H. J. (2009). Protein phosphatase 5 regulates the function of 53BP1 after neocarzinostatin-induced DNA damage. J. Biol. Chem. 284, 9845-9853.

Kang, H. C., Lee, Y.-I., Shin, J.-H., Andrabi, S. A., Chi, Z., Gagné, J.-P., Lee, Y., Ko, H. S., Lee, B. D., Poirier, G. G. et al. (2011). Iduna is a poly(ADP-ribose) (PAR)-dependent E3 ubiquitin ligase that regulates DNA damage. Proc. Natl. Acad. Sci. USA 108, 14103-14108.

Kastan, M. B., Onyekwere, O., Sidransky, D., Vogelstein, B. and Craig, R. W. (1991). Participation of p53 protein in the cellular response to DNA damage. Cancer Res. 51, 6304-6311. 
Kato, T. A., Okayasu, R. and Bedford, J. S. (2009). Signatures of DNA double strand breaks produced in irradiated $\mathrm{G} 1$ and $\mathrm{G} 2$ cells persist into mitosis. J. Cell. Physiol. 219, 760-765.

Keogh, M.-C., Kim, J.-A., Downey, M., Fillingham, J., Chowdhury, D., Harrison, J. C., Onishi, M., Datta, N., Galicia, S., Emili, A. et al. (2006). A phosphatase complex that dephosphorylates gammaH2AX regulates DNA damage checkpoint recovery. Nature 439, 497-501.

Kim, J.-A. and Haber, J. E. (2009). Chromatin assembly factors Asf1 and CAF-1 have overlapping roles in deactivating the DNA damage checkpoint when DNA repair is complete. Proc. Natl. Acad. Sci. USA 106, 1151-1156.

Kim, Y., Starostina, N. G. and Kipreos, E. T. (2008). The CRL4Cdt2 ubiquitin ligase targets the degradation of p21Cip1 to control replication licensing. Genes Dev. 22, 2507-2519.

Kleiblova, P., Shaltiel, I. A., Benada, J., Ševčík, J., Pecháčková, S., Pohlreich, P., Voest, E. E., Dundr, P., Bartek, J., Kleibl, Z. et al. (2013). Gain-of-function mutations of PPM1D/Wip1 impair the p53-dependent G1 checkpoint. J. Cell Biol. 201, 511-521.

Krenning, L., Feringa, F. M., Shaltiel, I. A., van den Berg, J. and Medema, R. H. (2014). Transient activation of p53 in G2 phase is sufficient to induce senescence. Mol. Cell 55, 59-72.

Krystyniak, A., Garcia-Echeverria, C., Prigent, C. and Ferrari, S. (2005). Inhibition of Aurora A in response to DNA damage. Oncogene 25, 338-348.

Kuo, C. Y., Li, X., Kong, X. Q., Luo, C., Chang, C. C., Chung, Y., Shih, H. M., Li, K. K. and Ann, D. K. (2014). An arginine-rich motif of ring finger protein 4 (RNF4) oversees the recruitment and degradation of the phosphorylated and SUMOylated Krüppel-associated box domain-associated protein 1 (KAP1)/ TRIM28 protein during genotoxic stress. J. Biol. Chem. 289, 20757-20772.

Lafarga, V., Cuadrado, A., Lopez de Silanes, I., Bengoechea, R., FernandezCapetillo, O. and Nebreda, A. R. (2009). p38 Mitogen-activated protein kinaseand HuR-dependent stabilization of p21(Cip1) mRNA mediates the $G(1) / S$ checkpoint. Mol. Cell. Biol. 29, 4341-4351.

Lahav, G., Rosenfeld, N., Sigal, A., Geva-Zatorsky, N., Levine, A. J., Elowitz, M. B. and Alon, U. (2004). Dynamics of the p53-Mdm2 feedback loop in individual cells. Nat. Genet. 36, 147-150.

Lancini, C., van den Berk, P. C. M., Vissers, J. H. A., Gargiulo, G., Song, J.-Y., Hulsman, D., Serresi, M., Tanger, E., Blom, M., Vens, C. et al. (2014). Tight regulation of ubiquitin-mediated DNA damage response by USP3 preserves the functional integrity of hematopoietic stem cells. J. Exp. Med. 211, 1759-1777.

Laoukili, J., Kooistra, M. R. H., Brás, A., Kauw, J., Kerkhoven, R. M., Morrison, A., Clevers, H. and Medema, R. H. (2005). FoxM1 is required for execution of the mitotic programme and chromosome stability. Nat. Cell Biol. 7, 126-136.

Laoukili, J., Alvarez, M., Meijer, L. A. T., Stahl, M., Mohammed, S., Kleij, L., Heck, A. J. R. and Medema, R. H. (2008). Activation of FoxM1 during G2 requires cyclin A/Cdk-dependent relief of autorepression by the FoxM1 Nterminal domain. Mol. Cell. Biol. 28, 3076-3087.

Lee, D.-H. and Chowdhury, D. (2011). What goes on must come off: phosphatases gate-crash the DNA damage response. Trends Biochem. Sci. 36, 569-577.

Lee, J.-H. and Paull, T. T. (2005). ATM activation by DNA double-strand breaks through the Mre11-Rad50-Nbs1 complex. Science 308, 551-554.

Lee, Y.-K., Thomas, S. N., Yang, A. J. and Ann, D. K. (2007). Doxorubicin downregulates Kruppel-associated box domain-associated protein 1 sumoylation that relieves its transcription repression on p21WAF1/CIP1 in breast cancer MCF-7 cells. J. Biol. Chem. 282, 1595-1606.

Lee, J., Kim, J. A., Barbier, V., Fotedar, A. and Fotedar, R. (2009). DNA damage triggers p21WAF1-dependent Emi1 down-regulation that maintains $\mathrm{G} 2$ arrest. Mol. Biol. Cell 20, 1891-1902.

Lee, D.-H., Goodarzi, A. A., Adelmant, G. O., Pan, Y., Jeggo, P. A., Marto, J. A and Chowdhury, D. (2012). Phosphoproteomic analysis reveals that PP4 dephosphorylates KAP-1 impacting the DNA damage response. EMBO J. 31 2403-2415.

Lee, D.-H., Acharya, S. S., Kwon, M., Drane, P., Guan, Y., Adelmant, G., Kalev, P., Shah, J., Pellman, D., Marto, J. A. et al. (2014). Dephosphorylation enables the recruitment of 53BP1 to double-strand DNA breaks. Mol. Cell 54, 512-525.

Leung-Pineda, V., Ryan, C. E. and Piwnica-Worms, H. (2006). Phosphorylation of Chk1 by ATR is antagonized by a Chk1-regulated protein phosphatase $2 \mathrm{~A}$ circuit. Mol. Cell. Biol. 26, 7529-7538.

Li, J., Yang, Y., Peng, Y., Austin, R. J., van Eyndhoven, W. G., Nguyen, K. C. Q., Gabriele, T., McCurrach, M. E., Marks, J. R., Hoey, T. et al. (2002). Oncogenic properties of PPM1D located within a breast cancer amplification epicenter at 17q23. Nat. Genet. 31, 133-134.

Li, X., Lee, Y.-K., Jeng, J.-C., Yen, Y., Schultz, D. C., Shih, H.-M. and Ann, D. K. (2007). Role for KAP1 serine 824 phosphorylation and sumoylation desumoylation switch in regulating KAP1-mediated transcriptional repression. J. Biol. Chem. 282, 36177-36189

Liang, X., Reed, E. and Yu, J. J. (2006). Protein phosphatase 2A interacts with Chk2 and regulates phosphorylation at Thr-68 after cisplatin treatment of human ovarian cancer cells. Int. J. Mol. Med. 17, 703-708.

Liang, H., Esposito, A., De, S., Ber, S., Collin, P., Surana, U. and Venkitaraman, A. R. (2014). Homeostatic control of polo-like kinase-1 engenders non-genetic heterogeneity in G2 checkpoint fidelity and timing. Nat. Commun. 5, 4048 .

Lindqvist, A., de Bruijn, M., Macurek, L., Brás, A., Mensinga, A., Bruinsma, W., Voets, O., Kranenburg, O. and Medema, R. H. (2009a). Wip1 confers G2 checkpoint recovery competence by counteracting p53-dependent transcriptional repression. EMBO J. 28, 3196-3206.
Lindqvist, A., Rodríguez-Bravo, V. and Medema, R. H. (2009b). The decision to enter mitosis: feedback and redundancy in the mitotic entry network. J. Cell Biol. 185, 193-202.

Liu, Q., Guntuku, S., Cui, X. S., Matsuoka, S., Cortez, D., Tamai, K., Luo, G., Carattini-Rivera, S., DeMayo, F., Bradley, A. et al. (2000). Chk1 is an essential kinase that is regulated by Atr and required for the $\mathrm{G}(2) / \mathrm{M}$ DNA damage checkpoint. Genes Dev. 14, 1448-1459.

Liu, X. S., Li, H., Song, B. and Liu, X. (2010). Polo-like kinase 1 phosphorylation of $\mathrm{G} 2$ and S-phase-expressed 1 protein is essential for p53 inactivation during G2 checkpoint recovery. EMBO Rep. 11, 626-632.

Lock, R. B. and Ross, W. E. (1990). Inhibition of p34cdc2 kinase activity by etoposide or irradiation as a mechanism of G2 arrest in Chinese hamster ovary cells. Cancer Res. 50, 3761-3766.

Loewer, A., Batchelor, E., Gaglia, G. and Lahav, G. (2010). Basal dynamics of p53 reveal transcriptionally attenuated pulses in cycling cells. Cell 142, 89-100.

Loewer, A., Karanam, K., Mock, C. and Lahav, G. (2013). The p53 response in single cells is linearly correlated to the number of DNA breaks without a distinct threshold. BMC Biol. 11, 114.

Lou, Z., Minter-Dykhouse, K., Franco, S., Gostissa, M., Rivera, M. A., Celeste, A., Manis, J. P., van Deursen, J., Nussenzweig, A., Paull, T. T. et al. (2006). MDC1 maintains genomic stability by participating in the amplification of ATMdependent DNA damage signals. Mol. Cell 21, 187-200.

Lowery, D. M., Clauser, K. R., Hjerrild, M., Lim, D., Alexander, J., Kishi, K., Ong, S.-E., Gammeltoft, S., Carr, S. A. and Yaffe, M. B. (2007). Proteomic screen defines the Polo-box domain interactome and identifies Rock2 as a Plk1 substrate. EMBO J. 26, 2262-2273.

Lu, X., Nannenga, B. and Donehower, L. A. (2005). PPM1D dephosphorylates Chk1 and p53 and abrogates cell cycle checkpoints. Genes Dev. 19, 1162-1174.

Lu, X., Ma, O., Nguyen, T.-A., Jones, S. N., Oren, M. and Donehower, L. A. (2007). The Wip1 Phosphatase acts as a gatekeeper in the p53-Mdm2 autoregulatory loop. Cancer Cell 12, 342-354.

Ludlow, J. W., Glendening, C. L., Livingston, D. M. and DeCarprio, J. A. (1993). Specific enzymatic dephosphorylation of the retinoblastoma protein. Mol. Cell. Biol. 13, 367-372.

Luo, J., Nikolaev, A. Y., Imai, S., Chen, D., Su, F., Shiloh, A., Guarente, L. and Gu, W. (2001). Negative control of p53 by Sir2alpha promotes cell survival under stress. Cell 107, 137-148.

Macůrek, L., Lindqvist, A., Lim, D., Lampson, M. A., Klompmaker, R., Freire, R., Clouin, C., Taylor, S. S., Yaffe, M. B. and Medema, R. H. (2008). Polo-like kinase- 1 is activated by aurora A to promote checkpoint recovery. Nature $\mathbf{4 5 5}$, 119-123.

Macůrek, L., Lindqvist, A., Voets, O., Kool, J., Vos, H. R. and Medema, R. H. (2010). Wip1 phosphatase is associated with chromatin and dephosphorylates gammaH2AX to promote checkpoint inhibition. Oncogene 29, 2281-2291.

Mailand, N., Falck, J., Lukas, C., Syljuâsen, R. G., Welcker, M., Bartek, J. and Lukas, J. (2000). Rapid destruction of human Cdc25A in response to DNA damage. Science 288, 1425-1429.

Mailand, N., Bekker-Jensen, S., Bartek, J. and Lukas, J. (2006). Destruction of Claspin by SCFbetaTrCP restrains Chk1 activation and facilitates recovery from genotoxic stress. Mol. Cell 23, 307-318.

Maity, A., Hwang, A., Janss, A., Phillips, P., McKenna, W. G. and Muschel, R. J. (1996). Delayed cyclin B1 expression during the G2 arrest following DNA damage. Oncogene 13,1647-1657.

Major, M. L., Lepe, R. and Costa, R. H. (2004). Forkhead box M1B transcriptional activity requires binding of $\mathrm{Cdk}$-cyclin complexes for phosphorylation-dependent recruitment of p300/CBP coactivators. Mol. Cell. Biol. 24, 2649-2661.

Mamely, I., van Vugt, M. A., Smits, V. A., Semple, J. I., Lemmens, B., Perrakis, A., Medema, R. H. and Freire, R. (2006). Polo-like kinase-1 controls proteasome-dependent degradation of Claspin during checkpoint recovery. Curr. Biol. 16, 1950-1955.

Mannefeld, M., Klassen, E. and Gaubatz, S. (2009). B-MYB is required for recovery from the DNA damage-induced G2 checkpoint in p53 mutant cells. Cancer Res. 69, 4073-4080.

Matsuoka, S., Huang, M. and Elledge, S. J. (1998). Linkage of ATM to cell cycle regulation by the Chk2 protein kinase. Science 282, 1893-1897.

Meek, D. W. and Anderson, C. W. (2009). Posttranslational modification of p53: cooperative integrators of function. Cold Spring Harb. Perspect. Biol. 1, a000950.

Menzel, T., Nähse-Kumpf, V., Kousholt, A. N., Klein, D. K., Lund-Andersen, C., Lees, M., Johansen, J. V., Syljuåsen, R. G. and Sørensen, C. S. (2011). A genetic screen identifies BRCA2 and PALB2 as key regulators of G2 checkpoint maintenance. EMBO Rep. 12, 705-712.

Mikhailov, A., Cole, R. W. and Rieder, C. L. (2002). DNA damage during mitosis in human cells delays the metaphase/anaphase transition via the spindleassembly checkpoint. Curr. Biol. 12, 1797-1806.

Miller, K. M., Tjeertes, J. V., Coates, J., Legube, G., Polo, S. E., Britton, S. and Jackson, S. P. (2010). Human HDAC1 and HDAC2 function in the DNAdamage response to promote DNA nonhomologous end-joining. Nat. Struct. Mol. Biol. 17, 1144-1151.

Moon, S.-H., Lin, L., Zhang, X., Nguyen, T.-A., Darlington, Y., Waldman, A. S., Lu, X. and Donehower, L. A. (2010). Wild-type p53-induced phosphatase 1 dephosphorylates histone variant gamma-H2AX and suppresses DNA double strand break repair. J. Biol. Chem. 285, 12935-12947.

Mosbech, A., Lukas, C., Bekker-Jensen, S. and Mailand, N. (2013). The deubiquitylating enzyme USP44 counteracts the DNA double-strand break 
response mediated by the RNF8 and RNF168 ubiquitin ligases. J. Biol. Chem 288, 16579-16587.

Müllers, E., Cascales, H. S., Jaiswal, H., Saurin, A. T. and Lindqvist, A. (2014). Nuclear translocation of Cyclin B1 marks the restriction point for terminal cell cycle exit in G2 phase. Cell Cycle 13, 2733-2743

Murga, M., Jaco, I., Fan, Y., Soria, R., Martinez-Pastor, B., Cuadrado, M., Yang, S.-M., Blasco, M. A., Skoultchi, A. I. and Fernandez-Capetillo, O. (2007) Global chromatin compaction limits the strength of the DNA damage response. J. Cell Biol. 178, 1101-1108

Myers, J. S., Zhao, R., Xu, X., Ham, A.-J. L. and Cortez, D. (2007). Cyclindependent kinase 2 dependent phosphorylation of ATRIP regulates the G2-M checkpoint response to DNA damage. Cancer Res. 67, 6685-6690.

Naetar, N., Soundarapandian, V., Litovchick, L., Goguen, K. L., Sablina, A. A., Bowman-Colin, C., Sicinski, P., Hahn, W. C., DeCaprio, J. A. and Livingston, D. M. (2014). PP2A-mediated regulation of Ras signaling in $G 2$ is essential for stable quiescence and normal G1 length. Mol. Cell 54, 932-945.

Naito, Y., Shimizu, H., Kasama, T., Sato, J., Tabara, H., Okamoto, A., Yabuta, N. and Nojima, H. (2012). Cyclin G-associated kinase regulates protein phosphatase 2A by phosphorylation of its $B^{\prime} \gamma$ subunit. Cell Cycle 11, 604-616.

Nakada, S., Chen, G. I., Gingras, A.-C. and Durocher, D. (2008). PP4 is a $\mathrm{H} 2 \mathrm{AX}$ phosphatase required for recovery from the DNA damage checkpoint EMBO Rep. 9, 1019-1026.

Nghiem, P., Park, P. K., Kim, Y., Vaziri, C. and Schreiber, S. L. (2001). ATR inhibition selectively sensitizes $\mathrm{G} 1$ checkpoint-deficient cells to lethal premature chromatin condensation. Proc. Natl. Acad. Sci. USA 98, 9092-9097.

Nishi, R., Wijnhoven, P., le Sage, C., Tjeertes, J., Galanty, Y., Forment, J. V., Clague, M. J., Urbé, S. and Jackson, S. P. (2014). Systematic characterization of deubiquitylating enzymes for roles in maintaining genome integrity. Nat. Cell Biol. 16, 1016-1026, , 1-8.

Noda, A., Hirai, Y., Hamasaki, K., Mitani, H., Nakamura, N. and Kodama, Y. (2012). Unrepairable DNA double-strand breaks that are generated by ionising radiation determine the fate of normal human cells. J. Cell Sci. 125, 5280-5287.

O'Connell, M. J., Raleigh, J. M., Verkade, H. M. and Nurse, P. (1997). Chk1 is a wee1 kinase in the G2 DNA damage checkpoint inhibiting cdc2 by $\mathrm{Y} 15$ phosphorylation. EMBO J. 16, 545-554.

Ochi, T., Wu, Q. and Blundell, T. L. (2014). The spatial organization of nonhomologous end joining: from bridging to end joining. DNA Repair (Amst.) 17, 98-109.

Oliveira, D. V., Kato, A., Nakamura, K., Ikura, T., Okada, M., Kobayashi, J., Yanagihara, H., Saito, Y., Tauchi, H. and Komatsu, K. (2014). Histone chaperone FACT regulates homologous recombination by chromatin remodeling through interaction with RNF20. J. Cell Sci. 127, 763-772.

Orthwein, A., Fradet-Turcotte, A., Noordermeer, S. M., Canny, M. D., Brun, C. M. Strecker, J., Escribano-Diaz, C. and Durocher, D. (2014). Mitosis inhibits DNA double-strand break repair to guard against telomere fusions. Science 344,189 193.

Painter, R. B. and Young, B. R. (1980). Radiosensitivity in ataxia-telangiectasia: a new explanation. Proc. Natl. Acad. Sci. USA 77, 7315-7317.

Paulovich, A. G., Toczyski, D. P. and Hartwell, L. H. (1997). When checkpoints fail. Cell 88, 315-321.

Paulsen, R. D. and Cimprich, K. A. (2007). The ATR pathway: fine-tuning the fork. DNA Repair (Amst.) 6, 953-966.

Peng, A., Lewellyn, A. L., Schiemann, W. P. and Maller, J. L. (2010). Repo-man controls a protein phosphatase 1-dependent threshold for DNA damage checkpoint activation. Curr. Biol. 20, 387-396.

Peschiaroli, A., Dorrello, N. V., Guardavaccaro, D., Venere, M., Halazonetis, T. Sherman, N. E. and Pagano, M. (2006). SCFbetaTrCP-mediated degradation of Claspin regulates recovery from the DNA replication checkpoint response. Mol. Cell 23, 319-329.

Pines, J. (1995). Cyclins and cyclin-dependent kinases: a biochemical view. Biochem. J. 308, 697-711.

Polo, S. E. (2014). Reshaping chromatin after DNA damage: the choreography of histone proteins. J. Mol. Biol.

Price, B. D. and D'Andrea, A. D. (2013). Chromatin remodeling at DNA doublestrand breaks. Cell 152, 1344-1354.

Primorac, I. and Musacchio, A. (2013). Panta rhei: the APC/C at steady state J. Cell Biol. 201, 177-189.

Purvis, J. E., Karhohs, K. W., Mock, C., Batchelor, E., Loewer, A. and Lahav, G. (2012). p53 dynamics control cell fate. Science 336, 1440-1444.

Qin, B., Gao, B., Yu, J., Yuan, J. and Lou, Z. (2013). Ataxia telangiectasiamutated- and Rad3-related protein regulates the DNA damage-induced G2/M checkpoint through the Aurora A cofactor Bora protein. J. Biol. Chem. 288 16139-16144.

Rainey, M. D., Charlton, M. E., Stanton, R. V. and Kastan, M. B. (2008) Transient inhibition of ATM kinase is sufficient to enhance cellular sensitivity to ionizing radiation. Cancer Res. 68, 7466-7474.

Raman, M., Earnest, S., Zhang, K., Zhao, Y. and Cobb, M. H. (2007). TAO kinases mediate activation of p38 in response to DNA damage. EMBO J. 26 2005-2014.

Reinhardt, H. C., Aslanian, A. S., Lees, J. A. and Yaffe, M. B. (2007). p53deficient cells rely on ATM- and ATR-mediated checkpoint signaling through the p38MAPK/MK2 pathway for survival after DNA damage. Cancer Cell 11, 175189.

Reinhardt, H. C., Hasskamp, P., Schmedding, I., Morandell, S., van Vugt, M. A. T. M., Wang, X., Linding, R., Ong, S.-E., Weaver, D., Carr, S. A. et al. (2010)
DNA damage activates a spatially distinct late cytoplasmic cell-cycle checkpoint network controlled by MK2-mediated RNA stabilization. Mol. Cell 40, 34-49.

Riley, T., Sontag, E., Chen, P. and Levine, A. (2008). Transcriptional control of human p53-regulated genes. Nat. Rev. Mol. Cell Biol. 9, 402-412.

Santra, M. K., Wajapeyee, N. and Green, M. R. (2009). F-box protein FBXO31 mediates cyclin D1 degradation to induce G1 arrest after DNA damage. Nature 459, 722-725.

Shaltiel, I. A., Aprelia, M., Saurin, A. T., Chowdhury, D., Kops, G. J. P. L., Voest, E. E. and Medema, R. H. (2014). Distinct phosphatases antagonize the p53 response in different phases of the cell cycle. Proc. Natl Acad. Sci. USA 111, 7313-7318.

Shanbhag, N. M., Rafalska-Metcalf, I. U., Balane-Bolivar, C., Janicki, S. M. and Greenberg, R. A. (2010). ATM-dependent chromatin changes silence transcription in cis to DNA double-strand breaks. Cell 141, 970-981.

Shao, G., Lilli, D. R., Patterson-Fortin, J., Coleman, K. A., Morrissey, D. E. and Greenberg, R. A. (2009). The Rap80-BRCC36 de-ubiquitinating enzyme complex antagonizes RNF8-Ubc13-dependent ubiquitination events at DNA double strand breaks. Proc. Natl. Acad. Sci. USA 106, 3166-3171.

Shibata, A., Barton, O., Noon, A. T., Dahm, K., Deckbar, D., Goodarzi, A. A., Löbrich, M. and Jeggo, P. A. (2010). Role of ATM and the damage response mediator proteins 53BP1 and MDC1 in the maintenance of $\mathrm{G}(2) / \mathrm{M}$ checkpoint arrest. Mol. Cell. Biol. 30, 3371-3383

Shimada, M. and Nakanishi, M. (2013). Response to DNA damage: why do we need to focus on protein phosphatases? Front Oncol 3, 8.

Shouse, G. P., Nobumori, Y., Panowicz, M. J. and Liu, X. (2011). ATM-mediated phosphorylation activates the tumor-suppressive function of B56 $\gamma$-PP2A. Oncogene 30, 3755-3765.

Shreeram, S., Demidov, O. N., Hee, W. K., Yamaguchi, H., Onishi, N., Kek, C., Timofeev, O. N., Dudgeon, C., Fornace, A. J., Anderson, C. W. et al. (2006). Wip1 phosphatase modulates ATM-dependent signaling pathways. Mol. Cell 23, 757-764.

Smits, V. A., Klompmaker, R., Arnaud, L., Rijksen, G., Nigg, E. A. and Medema, R. H. (2000). Polo-like kinase-1 is a target of the DNA damage checkpoint. Nat. Cell Biol. 2, 672-676.

Spencer, S. L., Cappell, S. D., Tsai, F.-C., Overton, K. W., Wang, C. L. and Meyer, T. (2013). The proliferation-quiescence decision is controlled by a bifurcation in CDK2 activity at mitotic exit. Cell 155, 369-383.

Stadler, W. M., Vaughn, D. J., Sonpavde, G., Vogelzang, N. J., Tagawa, S. T., Petrylak, D. P., Rosen, P., Lin, C.-C., Mahoney, J., Modi, S. et al. (2014). An open-label, single-arm, phase 2 trial of the Polo-like kinase inhibitor volasertib (BI 6727) in patients with locally advanced or metastatic urothelial cancer. Cancer 120, 976-982.

Stevenson, L. F., Sparks, A., Allende-Vega, N., Xirodimas, D. P., Lane, D. P. and Saville, M. K. (2007). The deubiquitinating enzyme USP2a regulates the p53 pathway by targeting Mdm2. EMBO J. 26, 976-986.

Stewart, G. S., Panier, S., Townsend, K., Al-Hakim, A. K., Kolas, N. K., Miller, E. S., Nakada, S., Ylanko, J., Olivarius, S., Mendez, M. et al. (2009). The RIDDLE syndrome protein mediates a ubiquitin-dependent signaling cascade at sites of DNA damage. Cell 136, 420-434

Stucki, M. and Jackson, S. P. (2006). gammaH2AX and MDC1: anchoring the DNA-damage-response machinery to broken chromosomes. DNA Repair (Amst.) 5, 534-543

Sudo, T., Ota, Y., Kotani, S., Nakao, M., Takami, Y., Takeda, S. and Saya, H. (2001). Activation of Cdh1-dependent APC is required for $\mathrm{G} 1$ cell cycle arrest and DNA damage-induced G2 checkpoint in vertebrate cells. EMBO J. 20, 6499-6508.

Syljuåsen, R. G., Jensen, S., Bartek, J. and Lukas, J. (2006). Adaptation to the ionizing radiation-induced $\mathrm{G} 2$ checkpoint occurs in human cells and depends on checkpoint kinase 1 and Polo-like kinase 1 kinases. Cancer Res. 66, 1025310257

Takai, H., Tominaga, K., Motoyama, N., Minamishima, Y. A., Nagahama, H., Tsukiyama, T., Ikeda, K., Nakayama, K., Nakanishi, M. and Nakayama, K. (2000). Aberrant cell cycle checkpoint function and early embryonic death in Chk1(-/-) mice. Genes Dev. 14, 1439-1447.

Takekawa, M., Adachi, M., Nakahata, A., Nakayama, I., Itoh, F., Tsukuda, H., Taya, Y. and Imai, K. (2000). p53-inducible wip1 phosphatase mediates a negative feedback regulation of p38 MAPK-p53 signaling in response to UV radiation. EMBO J.19,6517-6526.

Terasawa, M., Shinohara, A. and Shinohara, M. (2014). Canonical nonhomologous end joining in mitosis induces genome instability and is suppressed by M-phase-specific phosphorylation of XRCC4. PLoS Genet. 10, e1004563.

Toczyski, D. P., Galgoczy, D. J. and Hartwell, L. H. (1997). CDC5 and CKII control adaptation to the yeast DNA damage checkpoint. Cell 90, 1097-1106.

Tomimatsu, N., Mukherjee, B., Catherine Hardebeck, M., Ilcheva, M., Vanessa Camacho, C., Louise Harris, J., Porteus, M., Llorente, B., Khanna, K. K. and Burma, S. (2014). Phosphorylation of EXO1 by CDKs 1 and 2 regulates DNA end resection and repair pathway choice. Nat. Commun. 5, 3561.

van Vugt, M. A. T. M., Brás, A. and Medema, R. H. (2004). Polo-like kinase-1 controls recovery from a G2 DNA damage-induced arrest in mammalian cells. Mol. Cell 15, 799-811.

van Vugt, M. A. T. M., Bràs, A. and Medema, R. H. (2005). Restarting the cell cycle when the checkpoint comes to a halt. Cancer Res. 65, 7037-7040.

van Vugt, M. A. T. M., Gardino, A. K., Linding, R., Ostheimer, G. J., Reinhardt, H. C., Ong, S.-E., Tan, C. S., Miao, H., Keezer, S. M., Li, J. et al. (2010). A mitotic phosphorylation feedback network connects Cdk1, Plk1, 53BP1, and 
Chk2 to inactivate the G(2)/M DNA damage checkpoint. PLoS Biol. 8, e1000287.

Vaziri, H., Dessain, S. K., Ng Eaton, E., Imai, S. I., Frye, R. A., Pandita, T. K., Guarente, L. and Weinberg, R. A. (2001). hSIR2(SIRT1) functions as an NADdependent p53 deacetylase. Cell 107, 149-159.

Vidanes, G. M., Sweeney, F. D., Galicia, S., Cheung, S., Doyle, J. P., Durocher, D. and Toczyski, D. P. (2010). CDC5 inhibits the hyperphosphorylation of the checkpoint kinase Rad53, leading to checkpoint adaptation. PLoS Biol. 8, e1000286.

Wade, M., Li, Y.-C. and Wahl, G. M. (2013). MDM2, MDMX and p53 in oncogenesis and cancer therapy. Nat. Rev. Cancer 13, 83-96.

Wang, B., Zhao, A., Sun, L., Zhong, X., Zhong, J., Wang, H., Cai, M., Li, J., Xu, Y., Liao, J. et al. (2008). Protein phosphatase PP4 is overexpressed in human breast and lung tumors. Cell Res. 18, 974-977.

Wang, I.-C., Meliton, L., Ren, X., Zhang, Y., Balli, D., Snyder, J., Whitsett, J. A. Kalinichenko, V. V. and Kalin, T. V. (2009). Deletion of Forkhead Box M1 transcription factor from respiratory epithelial cells inhibits pulmonary tumorigenesis. PLoS ONE 4, e6609.

Wang, H., Shi, L. Z., Wong, C. C. L., Han, X., Hwang, P. Y.-H., Truong, L. N. Zhu, Q., Shao, Z., Chen, D. J., Berns, M. W. et al. (2013). The interaction of CtIP and Nbs1 connects CDK and ATM to regulate HR-mediated double-strand break repair. PLoS Genet. 9, e1003277.

Watanabe, N., Broome, M. and Hunter, T. (1995). Regulation of the human WEE1Hu CDK tyrosine 15-kinase during the cell cycle. EMBO J. 14, 18781891.

White, D., Rafalska-Metcalf, I. U., Ivanov, A. V., Corsinotti, A., Peng, H., Lee, S.-C., Trono, D., Janicki, S. M. and Rauscher, F. J., III (2012). The ATM substrate KAP1 controls DNA repair in heterochromatin: regulation by HP1 proteins and serine 473/824 phosphorylation. Mol. Cancer Res. 10, 401-414.

Wiebusch, L. and Hagemeier, C. (2010). p53- and p21-dependent premature APC/C-Cdh1 activation in G2 is part of the long-term response to genotoxic stress. Oncogene 29, 3477-3489.

Wierstra, I. (2013). FOXM1 (Forkhead box M1) in tumorigenesis: overexpression in human cancer, implication in tumorigenesis, oncogenic functions, tumorsuppressive properties, and target of anticancer therapy. Adv. Cancer Res. 119, 191-419.
Xu, N., Libertini, S., Black, E. J., Lao, Y., Hegarat, N., Walker, M. and Gillespie, D. A. (2012). Cdk-mediated phosphorylation of Chk1 is required for efficient activation and full checkpoint proficiency in response to DNA damage. Oncogene 31, 1086-1094.

Yamagata, K. and Kitabayashi, I. (2009). Sirt1 physically interacts with Tip60 and negatively regulates Tip60-mediated acetylation of H2AX. Biochem. Biophys. Res. Commun. 390, 1355-1360.

Yang, X., Li, H., Zhou, Z., Wang, W.-H., Deng, A., Andrisani, O. and Liu, X. (2009). Plk1-mediated phosphorylation of Topors regulates p53 stability. J. Biol. Chem. 284, 18588-18592.

Yang, X., Li, L., Liang, J., Shi, L., Yang, J., Yi, X., Zhang, D., Han, X., Yu, N. and Shang, Y. (2013). Histone acetyltransferase 1 promotes homologous recombination in DNA repair by facilitating histone turnover. J. Biol. Chem. 288, 18271-18282.

Yata, K., Bleuyard, J.-Y., Nakato, R., Ralf, C., Katou, Y., Schwab, R. A., Niedzwiedz, W., Shirahige, K. and Esashi, F. (2014). BRCA2 coordinates the activities of cell-cycle kinases to promote genome stability. Cell Reports 7, 15471559.

Ye, C., Zhang, X., Wan, J., Chang, L., Hu, W., Bing, Z., Zhang, S., Li, J., He, J., Wang, J. et al. (2013). Radiation-induced cellular senescence results from a slippage of long-term G2 arrested cells into G1 phase. Cell Cycle 12, 14241432.

Yoda, A., Xu, X. Z., Onishi, N., Toyoshima, K., Fujimoto, H., Kato, N., Oishi, I., Kondo, T. and Minami, Y. (2006). Intrinsic kinase activity and SQ/TQ domain of Chk2 kinase as well as $\mathrm{N}$-terminal domain of Wip1 phosphatase are required for regulation of Chk2 by Wip1. J. Biol. Chem. 281, 24847-24862.

You, Z., Harvey, K., Kong, L. and Newport, J. (2002). Xic1 degradation in Xenopus egg extracts is coupled to initiation of DNA replication. Genes Dev. 16, 1182-1194.

Zhang, J., Bao, S., Furumai, R., Kucera, K. S., Ali, A., Dean, N. M. and Wang, X.-F. (2005). Protein phosphatase 5 is required for ATR-mediated checkpoint activation. Mol. Cell. Biol. 25, 9910-9919.

Ziebold, U., Bartsch, O., Marais, R., Ferrari, S. and Klempnauer, K. H. (1997). Phosphorylation and activation of B-Myb by cyclin A-Cdk2. Curr. Biol. 7, 253-260.

Zou, L. and Elledge, S. J. (2003). Sensing DNA damage through ATRIP recognition of RPA-ssDNA complexes. Science 300, 1542-1548. 